\title{
Edaphic Factors as Agents of Genetic Diversity and Adaptation of Native Plant Species of Harsh Environments in the Brazilian Savanna
}

\section{Leide Rovênia Miranda Andrade ( $\sim$ leide.Andrade@embrapa.br)}

University of Brasilia https://orcid.org/0000-0003-0159-5109

\section{Fabiana Góis Aquino \\ University of Brasilia}

Guillaume Echevarria

2Université de Lorraine

Jamile S. Oliveira

University of Brasilia

Cícero D. Pereira

University of Brasilia

Juaci V. Malaquias

University of Brasilia

Karina Santos Souza

University of Brasilia

Emmanuelle Montargès-Pelletier

Université de Lorraine

Fábio Gelape Faleiro

University of Brasilia

Fábio Bueno Reis Júnior

University of Brasilia

Zenilton Gayoso Miranda

University of Brasilia

Edson Eyji Sano

University of Brasilia

\section{Research Article}

Keywords: Cerrado Biome, Ni-hyperaccumulators, Plant adaptation and conservation, Ultramafic soils

Posted Date: June 4th, 2021

DOl: https://doi.org/10.21203/rs.3.rs-575286/v1 
License: (c) (i) This work is licensed under a Creative Commons Attribution 4.0 International License. Read Full License 


\section{Abstract}

Purposes To analyze the main edaphic factors that differentiate ultramafic from typical Cerrado environments and act as agents of the development of biochemical and morphological mechanisms of species adaptation to these harsh environments; and to determine the genetic diversity of three Cerrado's shrubland native species (Justicia lanstyakii, Euploca salicoides, and Oxalis hirsutissima).

Methods We conducted chemical analysis of metal contents in soils, as well as on elemental composition, and analysis of DNA extracted from leaf tissues of the three species found in both environments. In leaves of $E$. salicoides grown in both environments we evaluated the changes in the levels of non-structural carbohydrates (NSC), and total proteins.

Results The accessions obtained in ultramafic soils were closer with each other, indicating genetic similarity and major differences in relation to the accessions collected in the Cerrado area. These differentiations probably are related with higher adaptation to soils rich in metals, mainly $\mathrm{Ni}$ in ultramafic, and Al in the Cerrado environments. The highest levels of NSC were observed in plants grown in ultramafic soils, including raffinose, which is related to responses to metal detoxification and drought. The allocation of $\mathrm{Ni}$ in the trichomes, which does not affect important processes of plant metabolism, is another mechanism developed by E. salicoides to overcome the hyperaccumulation of $\mathrm{Ni}$ in their tissues.

Conclusions These findings can help select seed collection sites representative of the genetic diversity of native plant species for restoring degraded areas or for phytoremediation of metals.

\section{Introduction}

The Brazilian tropical savanna (Cerrado biome) occupies an area of more than 203 million hectares in the centre of the country, corresponding to more than $23 \%$ of the national territory. The climate is characterized as Koppen's Aw (tropical savanna climate with dry winter), with two well-defined seasons: a six-month dry season (May to October) and six-month rainy season (November to April) (Silva et al. 2008). This biome is one of the most diverse tropical savannas, with 11,046 species of phanerogams in which 40\% are endemic (Mendonça et al. 2008; Myers et al. 2000). The high diversity of plants and the high degree of endemism found in this biome results from the great heterogeneity of habitats. One of the factors that determine the development of this diversified flora is the geochemistry of the soils, mainly due to the presence of metallic elements in high concentrations, such as $\mathrm{Ni}$ in soils derived from ultramafic rocks, and $\mathrm{Al}$ in acidic Ferralsol.

More than $80 \%$ of the Cerrado region present soils that are naturally low in nutrients and rich in $\mathrm{Al}, \mathrm{Fe}$, and $\mathrm{Si}$ (Martins et al. 2010). The Ferralsol, which is highly weathered, deep, well-structured, well drained, deficient in macro (P, K, Mg, and $\mathrm{Ca}$ ) and micronutrients ( $\mathrm{Co}, \mathrm{Cu}, \mathrm{Mn}$, and $\mathrm{Zn}$ ), are the dominant soil type in the Cerrado (> $46 \%$ in area). Their occurrence in flat topography, known as chapadas, favors intensive and highly mechanized grain production. The vegetation is composed of a mosaic of grasslands, shrublands, and forestlands in different proportions, depending on the availability of water and nutrients 
of each region (Ratter et al. 1997). Currently, $45 \%$ of the Cerrado biome are occupied by some type of land use, especially by cultivated pastures and annual croplands (Alencar et al. 2020).

Ultramafic rocks occupy only $0.2 \%$ (408,000 ha) of the Cerrado biome. Nevertheless, they have high economic value due to the mineral exploitation of metals, mainly $\mathrm{Ni}$, and ecological importance, since they host specific local biodiversity, which we only partially know, with a high potential for biotechnological uses. Ultramafic rocks in the central part of the Cerrado biome occur as isolated, flat islands (plateaus), with varying sizes and distances from each other, more specifically in the municipalities of Canabrava, Niquelândia and Barro Alto, Goiás State (Martins et al. 2010). Similar to the ultramafic zones in the world, soils derived from serpentinized ultramafic rocks in the region have more than $70 \%$ of mafic minerals rich in $\mathrm{Fe}, \mathrm{Mg}, \mathrm{Cr}, \mathrm{Ni}, \mathrm{Co}, \mathrm{Mn}, \mathrm{Zn}$, and $\mathrm{Cu}$. On the other hand, they are poor in $\mathrm{Si}, \mathrm{Al}, \mathrm{Ca}, \mathrm{P}, \mathrm{K}$, and low $\mathrm{Ca}: \mathrm{Mg}$ ratio. They are sometimes stony, with a special chemical and mineralogical constitution (Echevarria 2021; Vidal-Torrado et al. 2006). The B horizon is variable in both extension and degree of development.

The native vegetation found on ultramafic soils usually is tolerant to extreme soil conditions, presents low primary productivity, high endemism, and often is highly contrasting with the neighboring vegetation without ultramafic influence (Brady et al. 2005). As the edaphic conditions of ultramafic environments are very restrictive for the development of plants, they are considered harsh environments and can act as rigorous agents of ecotypic selection of plants (Kruckeberg 2002). In addition, the plant-soil associations found in the ultramafic environments may correlate with the biochemical isolation factor, indicating important areas for biological conservation (Martins et al., 2010). However, Ni mining activities in this region are causing loss of the local biodiversity.

The municipality of Barro Alto has one of the world's largest reserves of Ni. Its ore deposits are estimated at 120 million tons, with 1.25 million tons of $\mathrm{Ni}$ (Anglo American, 2011). Unlike Ni mining in the Niquelândia massif, which has lasted for almost 30 years and is close to depletion, the Ni exploration project in the region started in 2007. The suppression of the natural vegetation started to be accelerated in 2011, with the intensification of the Ni extraction. However, efforts have been made recently aiming to mitigate the impacts on flora by revegetating degraded areas related to Ni exploration with native plant species. Botanical surveys carried out in the ultramafic soils of Barro Alto covered by native vegetation identified more than 150 native species, without report of endemic species. Approximately $10 \%$ of these species are considered Ni hyperaccumulators, according to the criteria proposed by Baker and Brooks (1989) (Andrade et al. 2015; Aquino et al. 2011). These species have high biotechnological potential since they can be used in the process of Ni-phytoextraction, which consists in the extraction of the metal with the agronomic cultivation of these species in Ni-contaminated soils. The harvest of the aboveground tissues of the plants results in soil "cleaning" or Ni phytomining (agromining), when the plants are grown on soils that already have been mined, but still contain high levels of the metal, and with subsequently incineration of aerial biomass to retrieve Ni from the ashes (van der Ent et al. 2015a). 
Ni can display high bioavailability in ultramafic soils. Once it is absorbed by plants, it acts as a cofactor for urease for many plant species, an enzyme that hydrolyzes urea into ammonium and $\mathrm{CO}_{2}$, and it is also involved in several other physiological processes, that may include transport of nutrients to the seed and movement of Fe into the plant cells (Brown et al. 1987). It is therefore a micronutrient that is essential for plant metabolism (Pennazio 2012), including hyperaccumulator plants (Sellami et al. 2012). However, when absorbed in high concentrations it can be toxic. Ni toxicity causes water and nutrient imbalances, reducing plant growth and metabolism. On the other hand, Al, a major constituent of the continental crust and especially a predominant metal in acid and highly weathered soils of the Cerrado region, is quite toxic for sensitive species, causing severe effects on root development, plant growth, absorption of water and essential elements, sometimes leading to plant death. In order to overcome these toxicities, the vegetation growing on both ultramafic and non-ultramafic Cerrado soils developed specific mechanisms of metal tolerance that allowed their survival, involving chemical, physical and biotic components present in such harsh environments. It is noteworthy that several hundreds of $\mathrm{Ni}$ and $\mathrm{Al}$ hyperaccumulator species have developed mechanisms to tolerate these metals in such environments (Andrade et al. 2011; Jansen et al. 2002; Reeves et al. 2007).

Native species in ultramafic environments of Cerrado biome are natural candidates to recover mining areas or to be used in metal phytoextraction processes in urban and agricultural soils contaminated with these elements. During mining operations, vegetation covering ore deposits is completely removed so that in some cases, it is not possible to restore the original environment throughout mining closure process. Although they are not endemic to the ultramafic environment, some species can exhibit high interspecific diversity that directly affects recovery strategies. In addition, propagules collected in nonultramafic environments may be poorly adapted for use in mining recovery procedures in ultramafic areas.

The objectives of this work are three-fold: i) to analyze the main edaphic factors that differentiate ultramafic from typical Cerrado environments; ii) to analyze the main edaphic factors that act as agents of the development of biochemical and morphological mechanisms of species adaptation to these harsh environments and iii) to determine the genetic diversity of two Ni hyperaccumulator native species Justicia lanstyachii (Acanthaceae) and Euploca salicoides (Boraginaceae) and one intermediary Oxalis hirsutissima (Oxalidaceae) species that occurs in the Cerrado's shrubland. Although these species are common in Ni-rich areas, they are not endemic of ultramafic soils, growing in soils with different availability of metals. The three species have the potential to be used in the recovery of degraded areas by Ni mining or in the phytoremediation processes of this metal (Andrade et al. 2015).

Euploca salicoides, is a facultative hyperaccumulating $\mathrm{Ni}$ and Al species and is considered as a "plant model adapted to environments rich in metals". Studies were also conducted in order to clarify which type of tolerance mechanisms (biochemical, morphological) occur in this species that allows its development in areas with high bioavailability of either Ni (ultramafic environment) or Al (typical Cerrado environment). Here, we investigated whether the basal metabolism of plants is altered in the presence of greater 
availability of metals (mainly $\mathrm{Ni}$ and $\mathrm{Al}$ ) in the soils and the location of $\mathrm{Ni}$ in cellular structures in the leaves of plants from the ultramafic area.

\section{Materials And Methods}

We carried out this work in ultramafic soils with high Ni bioavailability (SAP), located in the municipality of Barro Alto, Goiás State, and in non-ultramafic typical Cerrado environments constituted by Cambisol (CAM) and Ferralsol (LV), with high Al bioavailability, located in Brasília, Federal District (FD) of Brazil.

Study area

The selected study areas are located in the municipality of Barro Alto, Goiás State and in Federal District (FD) of Brazil (Fig. 1). The first area is located in the Barro Alto mafic-ultramafic complex which is aligned with the intrusions of Niquelândia and Cana Brava for approximately $350 \mathrm{~km}$ extension along a NE-SW structural zone (CPRM 2010). The complex is subdivided into Lower Layered Series and Upper Layered Series. Our study area covers the Lower Layered Series which in turn is subdivided into Lower Mafic Zone and Ultramafic Zone. (Baeta Jr. 1986).

The ultramafic massif of Barro Alto occurs in shallow soils, with rocky outcrops, and strong undulating relief. The vegetation is adapted to the high levels of heavy metals and prolonged water deficit and is composed mostly of herbaceous plants, with sparsely distributed shrubs, and rare trees. According to the vegetation classification system proposed by Ribeiro and Walter (2008), there is a mosaic of phytophysiognomies composed of Campo Sujo (grassland), Campo Rupestre (rupestrian grassland) and Cerrado Rupestre (rupestrian Cerrado).

The second study area is located in the FD of Brazil, more specifically, in the ferruginous detritus-lateritic deposit of Tertiary-Quaternary age, which covers a large portion of the study area (CPRM, 2010). This unit is surrounded by different types of Neoproterozoic lithologies from Paranoá, Canastra, and Bambuí Groups. We can notice a large extension of urban areas covering this study site (Fi. 1).

Soil sampling for chemical and agronomic characterization of the study sites

In the ultramafic (SAP and LAT) and typical Cerrado soils (CAM and LV) sites, three composed soil samples, each one was constituted by $10-30$ subsamples, were collected at the $0-20 \mathrm{~cm}$ soil depth using a "dutch" auger. The samples were air-dried, ground and passed through a $2 \mathrm{~mm}$ sieve in the Soil Laboratory of the Embrapa Cerrados. The chemical and agronomic characterization of the soils were carried out through the following analyzes, according to the procedures described by Embrapa (1999): organic matter (O.M.); $\mathrm{pH}$ in water (1:2.5); exchangeable $\mathrm{Ca}^{2+}, \mathrm{Mg}^{2+}$, and $\mathrm{Al}^{3+}$ extracted by $\mathrm{KCl} 1 \mathrm{~N} ; \mathrm{P}$ and $\mathrm{K}$, extracted with Mehlich-1 solution $\left(0.05 \mathrm{M} \mathrm{HCl}+0.0125 \mathrm{M} \mathrm{H}_{2} \mathrm{SO}_{4}\right)$; potential acidity $(\mathrm{H}+\mathrm{Al})$, extracted with $0.01 \mathrm{M}$ calcium acetate at $\mathrm{pH}$ 7. $\mathrm{Co}, \mathrm{Cu}, \mathrm{Fe}, \mathrm{Mn}, \mathrm{Ni}$ and $\mathrm{Zn}$ were extracted with DTPA solution (bioavailable contents), according to methodologies described by Baker and Amacher (1982), and with 
aqua regia (extractable content) (ISO 1995), analyzed by inductively coupled plasma optical emission spectroscopy (ICP-OES, Thermo Fisher Scientific 7000).

Anglo American Mining Company provided information on the predominant mineralogy of these sites, such as the characteristics of the soil's parent material and total levels of $\mathrm{Ni}, \mathrm{MgO}, \mathrm{Fe}, \mathrm{SiO}_{2}$ and $\mathrm{Al}_{2} \mathrm{O}_{3}$ were kindly provided by, with soil sampling density of $25 \mathrm{mx} 25 \mathrm{~m}$ (data not shown).

Field plant sampling

In the region of ultramafic massif of Barro Alto, with soils with different levels of $\mathrm{Ni}$ availability (Andrade et al. 2015), above-ground tissues (leaves and stems) of Justicia lanstyakii Rizzini (Acanthaceae), Euploca salicoides (Cham.) J. I. M. Melo \& Smir (Boraginaceae) and Oxalis hirsutissima Mart. Ex Zucc. (Oxalidaceae) plants species were sampled in areas with predominance of Campo Sujo (Table 1). In the botanic surveys mentioned above, at least one individual of those species collected in the area was found to hyperaccumulate $\mathrm{Ni}$ in above ground tissues. This also applies to specimens of $E$. salicoides sampled in ultramafic or typical Cerrado soils in relation to the hyperaccumulation of Al in the tissues.

Collection of plants for DNA, biochemical, and metal content analysis, and for localization of metals in leaf structures

In each site described in Table 1, at different times and according to the objective of the study, the shoot (leaves and stems) of various plants of each species, randomly distributed on the ground, was collected. The collected materials were packed in paper or plastic bags, identified and taken to the Laboratory of Chemical Analysis of Plants, for elemental characterization, and to the Laboratory of Plant Genetics and Molecular Biology for DNA analysis, both from Embrapa Cerrados. E. salicoides plants were taken to the Laboratory of Plant Physiology of the Department of Botany, University of Brasília (UnB), for analysis of non-structural carbohydrates and total proteins. With the authorization issued by the Brazilian Institute of Environment and Renewable Natural Resources (IBAMA) (Special Authorization No. 02/2008), the plant tissue of E. salicoides (ES) species collected in the SAP5 site were prepared for identification, localization and semi-quantification of chemical elements at the tissue level, using scanning electron microscopy (SEM) and Energy-dispersion X-ray spectroscopy (EDXS), at the microscopy service (SCMEM) of the Faculty of Science and Technologies of Nancy (Université de Lorraine), Nancy, France.

\section{a) Sample processing for DNA extraction}

In the ultramafic (SAP5, SAP7, and SAP9) and the typical Cerrado (CAM) sites, shoots (leaves and stems) of two to three individuals were collected to form a composite sample of each species of $E$. salicoides (EU), O. hirsutissima $(\mathrm{OH})$ and J. lanstyakii (JL), totaling 14 botanical accessions, as described in Table 2. The selected plants were in good vegetative condition and were growing more than two meters apart. The collected materials were packed in plastic bags, identified, placed in a polystyrene box with ice, until delivery, on the same day, to the Laboratory of Plant Genetics and Molecular Biology, where they were 
processed and aliquoted for DNA analysis and forwarding the rest of the plant material to the Laboratory of Plant Chemical Analysis.

Samples of genomic DNA from each access were extracted using the modified CTAB methodology (Faleiro et al. 2003) and with the use of washing in Sorbitol buffer ( $0.35 \mathrm{M})$. The amount of DNA was estimated by spectrophotometry at $260 \mathrm{~nm}$ (A260) and the A260/A280 ratio was used to evaluate the purity and quality of the samples (Sambroock et al. 1989). The DNA samples from each accession were

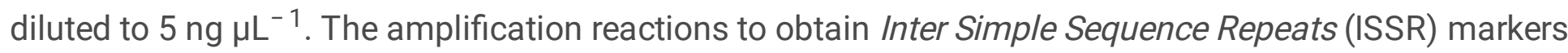
were carried out with $4.9 \mu \mathrm{L}$ of Milli Q water $1.3 \mu \mathrm{L}$ of buffer; $0.39 \mu \mathrm{L}$ of $50 \mathrm{mM} \mathrm{MgCl}{ }_{2} ; 0.26 \mu \mathrm{L}$ of deoxyribonucleotides (dATP, dTTP, dGTP and dCTP) $10 \mu \mathrm{M} ; 1.95 \mu \mathrm{L}$ of a $2 \mu \mathrm{M}$ primer (Operon Technologies Inc., Alameda, CA, USA); $0.2 \mu \mathrm{L}$ of the Taq DNA polymerase enzyme (1 unit); and $3 \mu \mathrm{L}$ of DNA (15 ng) (total volume of $13 \mu \mathrm{L}$ ). Initially, 18 ISSR primers were tested (Table 3). From these tests, eight primers were selected and used to obtain ISSR markers that generated a greater number of polymorphic bands and presented better quality of amplifications.

The amplifications were performed in a thermocycler, in which the samples were initially denatured at $94^{\circ} \mathrm{C}$ for 2 min, followed by 37 cycles, starting with 15 seconds at $94^{\circ} \mathrm{C}$; then 30 seconds at $47^{\circ} \mathrm{C}$ and $72^{\circ} \mathrm{C}$ per $1 \mathrm{~min}$. At the end of all cycles, the process was completed in $7 \mathrm{~min}$ at $72^{\circ} \mathrm{C}$ and cooled to $4^{\circ} \mathrm{C}$.

After amplification, $3 \mu$ l of a mixture of bromophenol blue $(0.25 \%)$ and glycerol (60\%) in water was added to each sample. These samples were applied on an agarose gel (1.2\%), stained with ethidium bromide, submerged in a TBE buffer ( $90 \mathrm{mM}$ Tris-Borate, $1 \mathrm{mM}$ EDTA). The electrophoretic separation was approximately four hours, at $90 \mathrm{~V}$. At the end of the race, the gels were photographed under ultraviolet light.

b) Preparation of samples for chemical analysis of leaf tissues

After removing the aliquot for DNA analysis, all remaining tissue material (leaves and stems) from each sample, together with samples of other specimens collected at the same sites, were sent to the Laboratory of Plant Chemistry Analysis for element characterization. The materials were slightly immersed in tap water and then in deionized water, to remove soil particles, and left on a bench until it dried at room temperature. The materials were then taken to a forced air oven at a temperature of $40^{\circ} \mathrm{C}$, until reach constant weight. After drying, the leaf tissues were finely crushed in a knife mill and mineralized by moist digestion, in a mixture of perchloric acid and hydrogen peroxide, in the 2:1 proportion ( $\mathrm{v} / \mathrm{v}$ ), respectively, to determine the levels of $\mathrm{Ca}, \mathrm{K}, \mathrm{Mg}, \mathrm{P}, \mathrm{S}, \mathrm{Co}, \mathrm{Cu}, \mathrm{Fe}, \mathrm{Ni}, \mathrm{Mn}$, and $\mathrm{Zn}$ by ICPOES. The $\mathrm{N}$ was extracted by the micro-Khjeldahl method and determined by colorimetry (Embrapa 1999) or by flow injection analysis (FIA, Lachat Quikchem 6000 system), coupled with UV/VIS, method.

c) Morphological features and determination of non-structural carbohydrates and total proteins in $E$. salicoides plants originated from ultramafic (SAP) and Cerrado (LV) soils 
The $E$. salicoides species were collected in two sites of ultramafic soils, previously characterized as contrasting in relation to the bioavailable levels of Ni (Andrade et al. 2015): ES-P6 access, in a site with $100 \mathrm{mg} \mathrm{Ni} \mathrm{dm}^{-3}$ soil (LAT6), and ES-P5 access, in a site with $\sim 600 \mathrm{mg} \mathrm{Ni} \mathrm{dm}^{-3}$ soil (SAP5). The ES-LV access is originated from plants growing in typical Cerrado soil (red Latosol), with low total and bioavailable levels of heavy metals (Freitas et al. 1978; Martins et. al. 2004). The site was located on the UnB campus, in Brasília, FD.

In each of the sites mentioned above, in the morning and, in the peak of dry season (June to August), three plants growing apart on the ground were collected to determine the non-structural carbohydrates (soluble sugars, glucose, fructose, sucrose, raffinose, and starch) and the total proteins. Before being sent for destructive analysis, the numbers of inflorescences/plant and branches/stem, as well as length of the stems and of the internodes for each plant were obtained using a pachymeter.

d) Determination of total soluble sugars (TSS)

Leaves samples of $E$. salicoides were lyophilized and ground $(10 \mathrm{mg})$, for soluble sugars determination. The soluble sugars were extracted four times with $80 \%$ ethanol $(500 \mu \mathrm{L})$, at $80^{\circ} \mathrm{C}(40 \mathrm{~min}$.). After centrifugation (10,000 g, $10 \mathrm{~min}$ ), the supernatants were combined and depigmented by the modified Shannon method (Shanon 1968). In a separating funnel, the ethanolic fraction (2.0 mL), absolute ethanol $(0.5 \mathrm{~mL})$, chloroform $(3.0 \mathrm{~mL})$, and water $(5.5 \mathrm{~mL})$ were added in sequence. Separation occurred after a period of approximately $12 \mathrm{~h}$. The measurement of TSS was performed according to the phenol-sulfuric method (Dubois et al. 1956). For comparison purposes, a standard glucose curve (SIGMA) was used at concentrations of $0,5,10,20,40$, and $80 \mu \mathrm{g}$. Supernatants containing TSS were collected and reserved for further analysis. The precipitate was used to remove the other components.

For the analysis of TSS (sucrose, glucose, fructose, and raffinose), the alcoholic fractions were dried, resuspended in water $(1 \mathrm{~mL})$, passed through an anionic and cationic exchange column (Dowex), and analyzed by High Performance lon Exchange Chromatography with Detector of Integrated Amperometric Pulse (HPAEC/IPAD), in CarboPac PA-10 column (Dionex Corporation, Sunnyvale, Ca, USA), using an elution gradient with $200 \mathrm{mM} \mathrm{NaOH}$ in water (30 min.). The detector responses were compared with the patterns of glucose, fructose, sucrose, and raffinose at $0.625,1.25,2.5,5.0,10.0$, and $20.0 \mu \mathrm{M}$. The standard curve for each sugar was used to calculate the carbohydrate content in the leaves.

e) Starch determination

After removing the TSS, the starch in the precipitate was extracted twice with Bacillus licheniformis thermostable a-amylase (MEGAZYME - $\left.120 \mathrm{U} \mathrm{mL}^{-1}\right)(0.5 \mathrm{~mL})$ at $75^{\circ} \mathrm{C}$, for $30 \mathrm{~min}$, and twice with amyloglucosidase from the Aspergillus niger fungus (MEGAZYME $\left.-15 \mathrm{U} \cdot \mathrm{mL}^{-1}\right)(0.5 \mathrm{~mL})$ at $50^{\circ} \mathrm{C}$ and for $30 \mathrm{~min}$. At the end of the four incubations with the enzymatic extract $(2.0 \mathrm{~mL}), 100 \mathrm{~mL}$ of $0.8 \mathrm{M}$ perchloric acid was added to stop the reaction and to precipitate proteins. After centrifugation $(13,000 \mathrm{~g}$, $2 \mathrm{~min}$ ), the glucose released ( $50 \mu \mathrm{L}$ of extract) was dosed by the GODPOD enzymatic method, using 750 $\mu \mathrm{L}$ of the PAPLiquiform Glucose kit (CENTERLAB®), which contains glucose oxidase, peroxidase, 4- 
aminoantipyrine, and phenol. After incubation at $30^{\circ} \mathrm{C}$ and, for $15 \mathrm{~min}$, the glucose content was determined in a spectrophotometer at $490 \mathrm{~nm}$. The data obtained were compared with a standard glucose curve (SIGMA), at the concentrations of $0,5,10,20,30$, and $40 \mu \mathrm{g}$. The released glucose was calculated and adjusted (-10\%) for the mass of bound glucose that is present in the starch.

f) Determination of total proteins

The proteins were extracted four times with sodium phosphate buffered saline (PBS, $100 \mathrm{mM} \mathrm{pH} \mathrm{7.4)}(0.5$ $\mathrm{mL}$ ) for $1 \mathrm{~h}$, except the first, which remained $12 \mathrm{~h}$ at $4^{\circ} \mathrm{C}$. After centrifugation $(13,000 \mathrm{~g}, 10 \mathrm{~min}$.), the total proteins were dosed using the Bradford method (Bradford 1976). The data obtained were compared with a standard glucose curve (SIGMA), at the concentrations of $0,5,10,15,20$, and $25 \mu \mathrm{g}$. The released glucose was calculated and adjusted $(-10 \%)$ for the mass of bound glucose that is present in the starch.

g) Location of $\mathrm{Ni}$ in cell compartments of E. salicoides leaves, native to ultramafic soil, by SEM-EDXS

About three E. solicoides (ES-P5) plants were randomly collected, in the SAP5 ultramafic site for use in microscopic analysis for the location, distribution and relative concentration of $\mathrm{Ni}$ in the cells of the leaf tissue. Still in the field, the third pair of leaves that precedes the youngest leaflet were cut into small segments, with a stainless-steel blade. The cuttings were made in order to have leaf blade tissue and secondary ribs in the same segment and placed in a small test tube $(10 \mathrm{~mL})$ containing $5 \mathrm{~mL}$ of $70 \%$ alcohol. In the laboratory, about 10 segments of each sample were cut into thin pieces ( $1 \mathrm{~mm} \times 3 \mathrm{~mm})$, fixed in adhesive tape, placed on carbon cassettes ("stub") and dried at room temperature. In these samples, the location of $\mathrm{Ni}$ accumulation in tissues was analyzed by using SEM-EDXS (Hitachi-S4800 SEM), with accelerated power ranging from 5 to $15 \mathrm{KV}$.

\section{Statistical analysis}

Due to the fact that the assumption of normality was not met, the data of metal content in soil and

in leaf tissues were processed using non-parametric statistical analysis. The comparison between the medians of treatment was made based on the Kruskal-Wallis test at the significance level of $p \leq 0.05$. The principal component analysis (PCA) was used for the correlation of the sites according to the soil chemical characteristics and nutrient accumulation in leaf tissues. Understanding communality as the explanatory power of the variable by the factor, the value adopted was $>0.70$. In order to evaluate how the soils are grouped according to all chemical attributes together, a cluster analysis was carried out by Ward's method, considering the Euclidean distance (Bussab et al. 1990). Optimum number of clusters was verified by the Average silhouette method (Rousseeuw 1987).

In the DNA analysis, the generated ISSR markers were converted into a matrix of binary data, from which the genetic dissimilarity between the different genotypes was estimated, based on the complement of the Nei and Li similarity coefficient (Nei and Li 1979), using the Genes Program (Cruz 2013). The genetic similarity (GS) was given by: Sgij $=2 \mathrm{Nij} /(\mathrm{Ni}+\mathrm{Nj})$, where: $\mathrm{Nij}$ is the number of bands present in both $\mathrm{i}$ and 
j genotypes; and $\mathrm{Ni}$ and $\mathrm{Nj}$ are the number of bands present in i and $\mathrm{j}$ genotypes, respectively. By subtracting the unit's SG value by 1 (1 - SG), we obtained the genetic dissimilarity. The genetic dissimilarity matrix was used to perform cluster analysis, by the Unweighted pair group method arithmetic average (UPGMA) method (Sneath and Sokal 1973) as a clustering criterion, and the graphic dispersion based on multidimensional scales, using the main coordinate method.

To test the effects of treatments (type of soils) on the production of total sugars, proteins and starch by E. salicoides plants growing on different soils, the data were analyzed using a one-way ANOVA, followed by Tukey's test, when significance level was $<0.05$.

Statistical analyzes were performed using the SAS (SAS Institute Inc. 2008), Statistica (StatSoft Inc. 2007), and R software, version 3.6.0 (R Core Team 2019).

\section{Results}

\section{Soil fertility and geochemistry}

The agronomic characteristics and bioavailability of metals in the soils from the collection sites of the botanical accesses are described in Table 4. The ultramafic soils in the region of Barro Alto (SAP5, LAT6, SAP7, and SAP9), in addition to the greater bioavailability of $\mathrm{Co}, \mathrm{Cu}, \mathrm{Fe}, \mathrm{Mn}, \mathrm{Ni}$, and $\mathrm{Zn}$, presented medium to high levels of cation exchange capacity (CEC) at pH 7 (T), $\mathrm{pH}$ in water higher than 6 or even close to neutrality (i. e. SAP9), and higher base saturation (V > 50\%) than the Cerrado Soil (CAM) $(p<$ 0.05). The average $\mathrm{Mg}$ contribution to the $\mathrm{T}$ values $(\mathrm{Mg} / \mathrm{T}, \%)$ observed in SAP soils was higher than $55 \%$, in contrast to less than $4 \%$ of $\mathrm{Mg}$ saturation in the CAM soil.

The Cerrado soil (CAM) also showed a significantly higher exchangeable $\mathrm{Al}^{3+}$ and its $\mathrm{Mg}$ :Ca ratio was 10-34 times lower than the values of the four ultramafic soils with significant differences.

Results correspond to the average obtained from three composite samples per site, $0-20 \mathrm{~cm}$ depth: one composite sample was constituted by $10-30$ subsamples; $\mathrm{sd}=$ standard deviation. $\mathrm{OM}=$ organic matter; $\mathrm{H}+\mathrm{Al}=$ titratable acidity; $\mathrm{Al}, \mathrm{Ca}, \mathrm{Mg}$ extractable by $1 \mathrm{~N} \mathrm{KCl} ; \mathrm{K}$ and $\mathrm{P}$ extractable with Mehlich-1 solution; $\mathrm{Co}, \mathrm{Cu}, \mathrm{Fe}, \mathrm{Ni}, \mathrm{Mn}$, and $\mathrm{Zn}$ extractable with DTPA solution; $\mathrm{SB}=$ sum of bases; $\mathrm{CEC}=$ Cation exchange capacity at soil $\mathrm{pH} ; \mathrm{T}=\mathrm{CEC}$ at $\mathrm{pH} 7 ; \mathrm{V}=$ base saturation; $\mathrm{m}=\mathrm{Al}^{3+}$ saturation; means followed by the same letters within the same line are not statistically different, according to the Kruskal-Wallis test $(p \geq$ 0.05).

In the PCA analysis involving agronomic characteristics without the bioavailability of heavy metals ( $\mathrm{Ni}$, $\mathrm{Zn}, \mathrm{Co}, \mathrm{Mn}$, and $\mathrm{Fe}$ ), there was a clear separation between the sites of ultramafic soils and typical Cerrado soils (Fig. 2). The first principal component explained $52.5 \%$ of the variance, associated with the $\mathrm{pH}$, $\mathrm{TpH7}, \mathrm{BS}, \mathrm{Mg}$, and $\mathrm{Mg} / \mathrm{Ca}$ which were all statistically different between CAM and ultramafic soils. Therefore, this analysis clearly separated the typical Cerrado soil (CAM), which had negative values, from all the ultramafic soils which presented positive values in the PC1 graph. The soil samples from the FD 
(CAM) presented a major influence of $\mathrm{Al}^{3+}$ attribute. The second principal component explained $35.4 \%$ of the associated variance with a major influence of the $\mathrm{K}, \mathrm{P}, \mathrm{H}+\mathrm{Al}, \mathrm{Ca}$, and $\mathrm{OM}$ attributes (communalities for $\left.r^{2} \geq 0.7\right)$. Despite the correlation of the ultramafic sites shown by the PCA analysis, two distinct subgroups were formed, with a clear separation of the SAP5 soils on the upper and right side of the graph, with higher levels of $\mathrm{K}, \mathrm{P}, \mathrm{H}+\mathrm{Al}, \mathrm{Ca}$, and OM, and a group of the other three soils (LAT6, SAP7, and SAP9) on the bottom and right side, presenting significantly higher $\mathrm{pH}, \mathrm{Mg}, \mathrm{Mg}: \mathrm{Ca}$, and $\mathrm{BS}$.

Soils of ultramafic origin in the world are easily recognized for having high levels of heavy metals such as $\mathrm{Co}, \mathrm{Cr}, \mathrm{Cu}, \mathrm{Fe}, \mathrm{Mn}, \mathrm{Ni}$ and $\mathrm{Zn}$. However, the typicalCerrado soils are well documented as having low levels of these elements which are, with the exception of $\mathrm{Cr}$, essential for plant development (Correia et al, 2004). Considering only micronutrients in the PCA analysis, the first principal component explained $69.1 \%$ of the variance, with the soil bioavailable content of $\mathrm{Co}, \mathrm{Ni}$ and $\mathrm{Zn}$ as the correlation factors (communalities $\mathrm{r}^{2} \geq 0.70$ ), where the SAP7 and SAP5 are the soils that presented the highest levels of those metals, respectively (Table 4; Fig. 3a). In contrast, $\mathrm{Al}^{3+}$ and $\mathrm{Fe}^{3+}$ were strongly related to CAM soil. The second principal component explained $19.9 \%$ of the variance, indicating higher bioavailability of $\mathrm{Mn}$ and $\mathrm{Cu}$ in the SAP9 soil (Table 4; Fig. 3a). The LAT6 soil, despite being derived from ultramafic rocks rich in $\mathrm{Ni}$ and other micronutrients, has a weathering process that is different from the others, having undergone greater $\mathrm{Ni}$ and $\mathrm{Mg}$ leaching, and presenting a deeper soil profile $(>1 \mathrm{~m})$, similar to the CAM soil.

In the PCA analysis of metal contents (AR) in soil (Fig. 3b), the first principal component explained $58.4 \%$ of variance, which indicated separation in the right side, and in positive axis, SAP7 and SAP9, mainly by $\mathrm{Cu}, \mathrm{Cr}, \mathrm{Fe}$, and $\mathrm{Zn}$ attributes. In negative position, the SAP5 samples were grouped by $\mathrm{Co}, \mathrm{Mg}, \mathrm{Mn}$, and $\mathrm{Ni}$ contents in soils. The second principal component explained $29.7 \%$ of variance and, on the left and positive side, Al was the attribute which gathered the soils samples of CAM. Again, the LAT6 soil was in an intermediary position between the CAM, also a soil with a deep diagnostic horizon, and SAP5, rich in $\mathrm{Ni}$ and other metals.

In summary, considering the chemical characteristics of the soils (fertility attributes, semi-total and bioavailable levels of metals), it is evident the formation of two distinct groups (Fig. 4): Group 1, represented by the typical Cerrado soil (CAM) and Group 2, represented by ultramafic soils, which in turn are formed by the Sub-group 2.1 (SAP5), Sub-group 2.2 (LAT6), Sub-group 2.3 (SAP7), and Sub-group 2.4 (SASP9). This formation of clusters confirms previous findings. It clearly outlines another distinction between LAT6 on one side and SAP7 and SAP9 on the other side. In fact, the latter two show significantly higher T, CEC, Mg: $\mathrm{Ca}$, and $\mathrm{H}+\mathrm{Al}, \mathrm{Co}, \mathrm{Ni}$, and $\mathrm{Zn}$ values in comparison with those from LAT6, which is more weathered both mineralogically and chemically (lixiviation of elements). The collection of soils under study therefore constitutes a wide range of ultramafic soils with highly varied physical and chemical characteristics that are probably derived from local edaphic conditions. However, all ultramafic soils are clearly distinguishable from typical Cerrado.

\section{Elements characterization of botanical accesses}

Page $12 / 31$ 
The plants require many elements (or their ions) to maintain their normal metabolism and growth and they are taken primarily from the soil. This requirement is largely different among plant species, often between plants of the same species. The nutrient concentration in plant shoots varied widely among $E$. salicoides, J. lanstyakii and $O$. hirsutissima species and between analyzed samples of the same species growing in the same site, reflecting the spatial variation of the soil (data not shown). The average values of the accumulated elements in the shoot of the plants growing in SAP soils (independent of the site) and typical Cerrado soil (CAM) are shown in Table 5.

Regarding the accumulated elements in the shoots, the first and second principal components explained only $28.5 \%$ and $17.4 \%$ of the variance of the data, respectively (Fig. 5). This result indicates that the weight of the variables (concentration of nutrients in the tissues) did not oscillate significantly within the species growing in different soils sites, suggesting that the nutritional requirements are characteristic of the species, regardless of the place of growth. However, it reflects the availability of some elements in the soil, which in turn is regulated by geochemical and biological factors such as the content in the parent material, degree of weathering, $\mathrm{pH}$, redox potential, and microbiological activities. These factors will determine the excess and / or deficiency of the element in the root environment. This was the case of $\mathrm{Mn}$ and $\mathrm{Cu}$ in greater concentration in the tissues of plants growing in the CAM soil, although the bioavailability of these elements, indicated by the DTPA extractor, is much lower than those observed in the SAP soils (Table 4). On the other hand, higher availability of $\mathrm{Mg}, \mathrm{Co}, \mathrm{Ni}$ and, to a certain extent, $\mathrm{Zn}$ in ultramafic soils is reflected in higher absorption and accumulation of these nutrients in plant tissues. The $\mathrm{Mg}$ is also the dominant cation in the exchangeable sites ( $\mathrm{T}$ value) of SAP soils (Mg:T $>55 \%$ ), resulting in higher $\mathrm{Mg}: \mathrm{Ca}$ ratios in plant tissues.

\section{Plant diversity}

The analysis of the 14 accessions studied using eight primers generated 108 ISSR markers, with an average of 13.5 markers per primer. The high percentage of polymorphic markers and the high average of markers per primer demonstrated the high genetic variability between the accessions of the three species. This result can be explained by the number of accessions used and because they are from different species, and by the efficiency of the ISSR technique in the quantification of genetic diversity between the accessions.

Genetic dissimilarities ranged from 0.17 to 1.00 (Table 6). This range of values shows the analysis of accessions with different degrees of genetic proximity, being an expected result, considering that accessions of the same species and accessions of different species evolutionarily distant from each other were analyzed. The greatest distances were observed between the access of E. salicoides ES-CAM1 and ES-CAM2 collected in the typical Cerrado site and the other accessions of other species.

The smallest genetic distances were observed between the accessions of 0 . hirsutissima $\mathrm{OH}-\mathrm{P} 9$ and $\mathrm{OH}-$ $\mathrm{P} 7$ (0.17) and E. salicoides ES-P9 and ES-P7, and ES-P9 and ES-P5, both with genetic dissimilarities of 0.18 , collected in ultramafic sites. Cluster and graphical dispersion analysis showed the divergence between accessions (Fig. 6). 
In addition to the divergence between the accessions, the cluster analysis showed the formation of five similarity groups, considering the genetic distance 0.6 as the cutoff point: Group 1, formed by the ES-P5, ES-P7, ES-P9, and ES-CAM1 accessions (numbers in the graph: 1, 2, 3, and 12, respectively); Group 2, formed by the $\mathrm{OH}-\mathrm{P} 5, \mathrm{OH}-\mathrm{P} 7$, and $\mathrm{OH}-\mathrm{P9}$ accessions (numbers in the graph: 4, 5 and 6, respectively); Group 3 formed by JL-P5, JL-P7, JL-P9, and JL-CAM accessions (numbers in the graph: 7, 8, 9, and 10, respectively); Group 4 formed by the $\mathrm{OH}-\mathrm{CAM} 1$, and $\mathrm{OH}-\mathrm{CAM} 2$ accessions (numbers in the graph: 11 and 13, respectively); and Group 5, formed only by the ES-CAM2 access (number in the graph $=14$ ).

\section{Plants morphology and carbohydrate production}

Morphological aspects of plants growing in different environments shown in Fig. 7. Plants collected in the sites SAP5 and LAT6 have thinner branches, with well-spaced internodes and well-developed inflorescences. On the other hand, plants growing in non-ultramafic soil (LV) had reduced internodes distance, greater leafing, with accentuated hairiness in the leaves, stems and buds in the leaf axils.

The Fig. 8 shows the quantitative differences between the morphological parameters of E. salicoides plants from non-ultramafic soils and from the ultramafic zone of Goiás State in terms of number of branches, leaves and inflorescences per plant (a), average length of branches (b), and average length of internodes (c). There was no statistical difference in terms of number of branches, leaves and inflorescences per plant obtained from specimens collected in different sites and environments. However, plants growing in the ultramafic environment showed differences in growth, with greater length of branches and internodes, compared to those from the typical Cerrado.

To understand whether the basal metabolism of plants is altered in the presence of greater availability of heavy metals ( $\mathrm{Ni}$ and $\mathrm{Al}$ ) in the soil, analyses of the content of total soluble sugars (TSS), starch and total proteins were carried out in plants growing in ultramafic soils (SAP5 and LAT6) and typical Cerrado's soil (LV). The results shown in Fig. 9 indicates variations in the TSS levels in plants growing in these three sites. The highest levels of TSS were found in the specimens collected in the SAP5 soil, when compared with the performance of plants in other sites (Fig. 9a). The observed differences suggest a possible effect of the increased availability of Ni in the SAP5 soil and its influence on photosynthesis. In addition to the greater production of glucose and fructose (reducing sugars), there was an accumulation of sucrose and raffinose (non-reducing sugars) in plants growing in the same environment. In fact, raffinose was not detected in plants growing in LAT6 or in LV sites (Fig. 9c), soils with lower levels of Ni and with a soil deeper than SAP5 (Cambisol), whose greater restriction on root growth exposes plants to water stress during periods of drought in the region.

\section{Ni localization in the tissues of Euploca salicoides}

Metal-hyperaccumators plant species possess mechanisms to maintain adequate concentrations of metal ions (essential or not) in different cellular compartments to minimize the damage in important cell organelles (Andrade et al. 2011; Clemens 2001). In our study, using the SEM microscope coupled to an EDXS probe, we searched for $\mathrm{Ni}$ in various cell compartments where other metals were reported to 
accumulate in the leaves (e.g. epidermal cells, guard cells). We observed that the surface architecture on both sides of $E$. salicoides leaves was characterized by a dense pubescence formed by non-glandular trichomes. The trichome surface was microsculptured with numerous prominent protrusions. Ni allocation was observed only in the protrusions in trichomes of $E$. salicoides leaves collected in an ultramafic site (Fig. 10).

\section{Discussion}

Most cation exchange sites $(\mathrm{T})$ of ultramafic soils are occupied by $\mathrm{Mg}^{2+}$, causing a high $\mathrm{Mg}$ :Ca ratio ( $\mathrm{Mg}: \mathrm{Ca}>5$ ), which can be very toxic for the development of non-adapted plants. The predominance of $\mathrm{Mg}$ over $\mathrm{Ca}$, due to the presence of $\mathrm{Mg}$-rich weathering minerals, in addition to the presence of heavy metals ( $\mathrm{Ni}, \mathrm{Co}, \mathrm{Cu}, \mathrm{Mn}$, and $\mathrm{Zn}$, among others) at high levels, and the low levels of Al are the major features of soils derived from ultramafic rocks worldwide (Echevarria 2021). On the other hand, the Ferralsols with deep B-diagnostic horizon (soil depth $>50 \mathrm{~cm}$ ), and the Cambisols, with incipient B-horizon, are common soils in the typical Cerrado environment (more than $46 \%$ and $3 \%$, respectively) (Correia et al. 2004). Kaolinite, gibbsite, hematite and goethite are the main minerals of the clay fraction of the Ferrasols (Gomes et al. 2004). They are characterized by their acidity (usually $\mathrm{pH}<5$ ), strong weathering, absence of primary minerals, leaching of silica and complete loss of exchangeable base cations $\left(\mathrm{Ca}^{2+}, \mathrm{Mg}^{2+}, \mathrm{K}^{+}\right)$ from the soil profile, with residual enrichment of iron and aluminum oxides. This results in low $\mathrm{V}$, and with $\mathrm{Al}^{3+}$ occupying most of the exchange sites in the CEC, which is nevertheless very low due to the lack of $\mathrm{OM}$ and negatively-charged minerals (Table 4).

Among the four ultramafic soils which are clearly separated from the acidic Ferralsol, there is again a gradient of available $\mathrm{Ni}$ and $\mathrm{Mg}$ which causes a gradient in the fertility stress to plants. The cluster analysis clearly shows this gradient by separating the soils into three groups. The Ferralsol (LAT6) which corresponds to the less stressful environment, separated from the three Cambisol (SAP5, SAP7 and SAP9). Among the three Cambisol SAP7 and SAP9 were the most hostile for plant growth as the least developed (weathered soils) whereas SAP5 is significantly less toxic in terms of available $\mathrm{Ni}$ and excess of Mg. For different reasons, both the ultramafic and typical Cerrado soils have very low levels of available $\mathrm{Ca}, \mathrm{K}$, and $\mathrm{P}$ so they both cause a similar nutritional stress for plant species although the strong acidity of CAM soil contrasts with moderately acid to neutral ultramafic soils.

The phytophysiognomies that occur in the ultramafic zone of Barro Alto are structurally similar to those that occur in the typical Cerrado biome. In the case of Campo Sujo and Campo Rupestre, the dominant component is the herbaceous-sub-shrub stratum growing on shallow soils, and eventually in the presence of rocky outcrops. These characteristics offer some physical restriction to root growth and, consequently, subject to water stress in the driest periods of the year. What differentiates ultramafic environments from other areas of the Cerrado biome, in a very striking way, are the chemical characteristics and, possibly, the microbiota associated with the local flora. Pessoa-Filho et al. (2015) found differences in the bacterial community structures between the non-ultramafic soil and the two ultramafic soils located in the same sites of the present study. They found that the abundance of bacterial lineages between Sites 1 (SAP5) 
and 2 (LAT6) was different. These authors hypothesized that these phenomena could be attributed to the establishment of different plant communities growing on them, as indicated in the flora survey done in the same area by Aquino et al. (2011), rather than to the differences in the Ni availability in the soil. Indeed, rhizosphere communities are critical to the normal ecophysiological performance of a plant and are an important component of ultramafic environments due to their role in nutrient cycling.

According to Kabata-Pendias and Mukherjee (2007), the levels of Ni and $\mathrm{Co}$ in leaf tissues of the plants growing on ultramafic and non-ultramafic soils, as observed in this work, are considered toxic for several species, but they are the levels expected for native species in serpentine soils. In this environment, the three species are considered very tolerant to $\mathrm{Ni}$, including two $\mathrm{Ni}$ hyperaccumulators $\left(>1,000 \mathrm{mg} \mathrm{Ni} \mathrm{kg}{ }^{-1}\right.$ in dry matter), but do not meet the criterion of Co hyperaccumulators, which was recently defined as 300 mg Co kg${ }^{-1}$ (Reeves et al. 2018, 2021; van der Ent et al. 2013). On the other hand, accessions of the $E$. salicoides species also showed the capacity for hyperaccumulation of $\mathrm{Al}\left(>1,000 \mathrm{mg} \mathrm{kg}^{-1}\right.$ in dry matter) in the tissues of some specimens collected on typical Cerrado soils (data not shown). Therefore, this species is considered a facultative metal hyperaccumulator, that is, the capacity of hyperaccumulation of either $\mathrm{Ni}$ or Al seems to depend on the availability of the respective element in the soil in which the plant is growing.

Syndrome of ultramafic soils (i.e.'Serpentine syndrome') is related to the combined physical, chemical, and biological factors associated with serpentine soils (Kruckeberg, 2002). It manifests in the competition between $\mathrm{Mg}$, with high availability in the environment, and $\mathrm{Ca}$ for exchange sites on the root surfaces, resulting in Mg:Ca ratio > 1 and Ca deficiency. In typical Cerrado soils, as a result of lower Mg availability in the soil, the relationship between these nutrients in plant tissue is, in general, reversed. In our study, E. salicoides plants growing in ultramafic soils absorbed higher levels of $\mathrm{Ca}$ and $\mathrm{Mg}$ than plants in the Cerrado, however, regardless of the environment, in a greater proportion of $\mathrm{Ca}$, resulting in a similar $\mathrm{Mg}: \mathrm{Ca}$ ratio $(\mathrm{Mg}: \mathrm{Ca}<1)$. There was no effect in the $\mathrm{Mg}$ :Ca soil ratio so that the plants had a similar Mg:Ca balance among the three ultramafic Cambisols. One could suspect a genetic adaptation that helps the plant cope with a gradient of intensity of such toxic nutrient status.

Surprisingly, there seems to be no difference in Ni uptake among the three ultramafic Cambisols for any of the three plant species although they display clear differences in $\mathrm{Ni}$ availability. One reason could be that the level of available $\mathrm{Ni}$ is high in the three soils and none of the three is therefore limiting for $\mathrm{Ni}$ accumulation, although $\mathrm{O}$. hirsutissima is not characterized as Ni-hyperaccumulator. Calcium has an important role in the alleviation of growth inhibition by salts and metal stress. For instance, the supply of $\mathrm{Ca}$ to the growth medium of rice plants was reported to reduce the Ni translocation factor to the shoots where it could cause physiological disturbances (Aziz et al. 2014). In the ultramafic environment, the Ca:Ni ratio in E. salicoides plants was 8.5-fold higher than that observed in the J. lanstyakii species and 17 -fold higher than that of $\mathrm{O}$. hirsutissima. It is possible that the preference for $\mathrm{Ca}$ absorption is one of the physiological mechanisms developed by this species to avoid possible toxic effects of $\mathrm{Mg}$ and $\mathrm{Ni}$ on their above-ground tissues. 
The soils reflect quality of parent material, both physical properties and chemical content, which in turn affects plant's life. The results show that the accessions collected in ultramafic sites have a genetic differential, which may be associated with greater adaptation to soils rich in $\mathrm{Ni}, \mathrm{Cr}, \mathrm{Co}, \mathrm{Zn}, \mathrm{Mn}, \mathrm{Fe}$, and Mg. In fact, the PCA analysis regarding the accumulation of nutrients in the shoots (Fig. 5) indicated two well defined groups, separating the materials collected in ultramafic (SAP) from those in non-ultramafic areas. The determining factors for the separation were the higher concentrations of $\mathrm{Ni}$, $\mathrm{Co}$ and $\mathrm{Mg}: \mathrm{Ca}$ ratio in the tissues of the accessions of the ultramafic region and $\mathrm{Al}, \mathrm{Cu}, \mathrm{Mn}$, and $\mathrm{Ca}$ in the tissues of those collected in the non-ultramafic soils.

The genetic studies of the populations of three sites in the ultramafic area of Barro Alto showed that the accessions collected were closer with each other, thus indicating genetic similarity among ultramafic populations but major differences with the accessions collected on Cerrado environment. Similar results were obtained by Makela et al. (2016), who, in order to determine the level of genetic variation in populations of Quercus rubra from mining-damaged ecosystems, used the Random Amplified Polymorphism DNA (RAPD) marker system to assess the level of gene expression of candidate genes for $\mathrm{Ni}$ resistance. These authors reported that the genetic diversity in populations of $Q$. rubra adapted to metalliferous soils were genetically close, possibly due to the ability of pollen to disperse over long distances, which would favor gene flow. Pereira et al. (2004), also using the RAPD molecular marker technique, evaluated the effects of adapting plants to a stress condition, resulting from the presence of toxic metals in serpentine soils (originated from ultramafic rocks), on the genetic structure of Cerrado native populations of that environment and non-serpentine soils, growing well separated with each other. These authors did not observe significant divergences between the two native groups, also attributed to the occurrence of gene flow between each group. However, they detected a tendency for divergence between populations, suggesting that when colonizing the ultramafic environment, the two populations followed different evolutionary path.

Habitat isolation is the reduction in gene flow between populations caused by spatial separation of the habitats to which they are differently adapted (Mayr 1947). In the present study, the geographical distance between the places of collection of the accessions of $E$. salicoides was significant, around 250 $\mathrm{km}$ apart, leading to a low probability of gene flow between the native groups in the ultramafic zone of Barro Alto and that of non-ultramafic region, in Brasília, FD. Although there is genetic diversity between them, it is not possible to guarantee whether the groups diverged to the point of being considered different species or whether they should be considered separated ecotypes that developed specific adaptations to different habitats, with very distinct edaphic characteristics, in which they can explore, in order to survive and reproduce.

Plants growing in ultramafic soils produced more sugars and probably sustained the greatest growth in terms of branches and internodes. Accumulation of soluble sugars has also been found in plants exposed to stress by As and Zn (Ghnaya et al. 2010; Jha and Dubey 2004). The increase in sucrose and raffinose suggests a response to a mechanism of detoxification of metals, leading to a decrease in the levels of reducing sugars, which are potentially harmful to cells (Costa and Spitz 1997; Kim et al. 2003). 
The production of raffinose in plants is associated with an adaptive response to environmental stress, such as water stress and metal toxicity. In fact, raffinose was detected only in plants growing in SAP5, which is a Cambisol type (soil depth $<0.50 \mathrm{~m}$ ), where the plants are more susceptible to water stress than those growing in LAT6 and LV Ferrasol (both with soil depth $>1 \mathrm{~m}$ ) during the dry season that occurs in the region.

Protein content is related to stress (as drought), but the effect of stress depends on the development stage of the plant, species and genotypes, and the intensity and duration of stress (Lazcano and Lowatt 1999). In our study, the total protein content did not differ between the plants growing at the three sites (Fig. 9d). However, E. salicoides presented both morphological and molecular changes, indicating that the lack of differential abundance of proteins in the plant's proteome may be indirectly associated with these phenomena.

Nickel is the metal most commonly accumulated by plants. Of the approximately 700 species reported to accumulate metals, 500 accumulate $\mathrm{Ni}$ (Reeves et al. 2021). Studies on the distribution of $\mathrm{Ni}$ in hyperaccumulating plants have shown that leaves are the main site of accumulation of metals, more specifically, in epidermal cells far from guard cells (Gei et al. 2020; Paul et al. 2020; Psaras and Manetas 2001; Robinson et al. 2003; van der Ent et al. 2019). In our study, Ni allocation was observed in trichomes of E. salicoides leaves collected in ultramafic sites (Fig. 10), where it cannot affect important processes of plant metabolism. McNear et al. (2005) showed that metal accumulation in the trichome structure of Alyssum murale reveals the functional role of trichomes in metal storage and detoxification, although they are nonglandular and thus the secretion is not possible. This is, therefore, another mechanism developed by E. salicoides plants to deal with the excessive absorption of $\mathrm{Ni}$ from the soil and translocated to the upper tissues.

Hyperaccumulators are predominantly found in soils containing high levels of hyperaccumulated elements, suggesting that they have evolved in situ on these soils (Cappa and Pilon-Smits 2014). The strategy of hyperaccumulation of $\mathrm{Ni}$ or other metals does not seem to be dominant in the ultramafic flora of Barro Alto (Andrade et al. 2015; Reeves et al. 2007), similar to that observed by Kraemer (2010) in different serpentine ecosystems. Andrade et al. (2015) reported that Ni accumulation in plants grown in ultramafic soils were dependent on bioavailability of this metal in soils. Likewise, after the botanical identification process, none of the identified species has been confirmed as endemic to the studied environments. They can be found in other areas of Campo Sujo and Campo Rupestre, where plants do not hyperaccumulate metals due to the low availability in soils. Pollard et al. (2014) postulated that, in such species, the hyperaccumulation is an ancestral phylogenetic trait or an anomalous manifestation of physiological mechanisms evolved on "normal" soils, and may or may not have direct adaptive benefits. However, we noticed that some species growing in similar phytophysiognomies are unusual in both environments (observation data), indicating flora with distinctive species composition. Goolsby and Mason (2016) suggested that hyperaccumulation evolved as a by-product of selection for physiological processes unrelated to adaptation on metalliferous soils. On the other hand, van der Ent et al. (2015b) 
reported that extreme natural phenotypes such as hyperaccumulators evolved through positive, directional natural selection, rather than neutral genetic drift.

According to the results obtained in our study, in typical Cerrado soils, the plants of the three species accumulated, on average, less than $30 \mathrm{mg} \mathrm{kg}^{-1}$ of $\mathrm{Ni}$ in their shoots tissues, suggesting that the critical level of $\mathrm{Ni}$ for these species is closer to that of normal plants, as stated by Chang et al. (2002). In the ultramafic environment, reflecting the metal's bioavailability, the three species accumulated more than $600 \mathrm{mg} \mathrm{kg}^{-1}$ of $\mathrm{Ni}$, considered excessive for most species. The phenomenon of hyperaccumulation was observed in J. lanstyakii and E. salicoides, with no irreparable damage occurring at metabolic, physiological and / or morphological levels, as shown in studies with E. salicoides. Furthermore, there is no exceptional level of Ni hyperaccumulation in the hyperaccumulator flora of Barro Alto (Andrade et al. 2015; Reeves et al., 2007) despite the very high levels of available $\mathrm{Ni}$ in the soils, i.e. DTPA-extractable Ni can exceed $1000 \mathrm{mg} \mathrm{kg}^{-1}$, a value among the highest ever recorded for ultramafic soils globally (Lopez et al. 2019). Considering all these factors together, it seems that metal hyperaccumulation is not a crucial factor for the survival of these plants in the ultramafic environments. Nevertheless, it is the product of a series of internal physiological adjustments, as suggested by Goolsby and Mason (2016) and Pollard et al. (2014), that culminated in changes in the genetic structures of the populations that developed in both harsh environments.

The differences in the genetic level found in the accessions collected in different sites indicate that the plant species are adapted to local environmental conditions. The adaptation of plants to environments rich in metals, such as ultramafic soils, increases their importance for their cultivation in Ni-mining degraded soils or for use in phytoremediation processes of areas heavily contaminated with metals. These results reinforce the need of including, in conservation plans, this intraspecific biodiversity, ensuring the maintenance of the variability of the genetic pool of genotypes of local origin (McKay et al. 2005). On the other hand, the introduction of nonlocal genotypes negatively affects adjacent native populations adapted to local conditions through genetic contamination (gene flow) (Hufford and Mazer 2003), putting at risk the maintenance of characteristics of interest. However, ensuring genetic diversity is not always possible due to the small size of plant populations adapted to the local conditions and, consequently, to the propagule stock. In this sense, croplands are important to guarantee the perpetuation of the genetic diversity of the species through their reintroduction in degraded areas.

\section{Conclusions}

The accessions collected in ultramafic sites have showed genetic differentiations that may be related with higher adaptation to soils rich in metals, such as $\mathrm{Ni}, \mathrm{Cr}, \mathrm{Co}, \mathrm{Zn}, \mathrm{Mn}, \mathrm{Fe}$, and $\mathrm{Mg}$. These materials have high potential to be included in the list of species suitable for revegetation of degraded areas by $\mathrm{Ni}$ mining or for phytoremediation processes of soils contaminated by metals in urban, industrial, or agricultural fields. 
This study demonstrated the importance of the Ni-tolerant plants in the biodiversity conservation programs and in the genetic improvement of cultivated plants, being a valuable strategy for the development of plant materials with greater capacity for the accumulation of metals for use as elements of commercial interest for phytoremediation or phytomining.

\section{Declarations}

\section{Acknowledgments}

The authors acknowledge the employees of Embrapa Cerrados laboratories for their assistance in carrying out chemical, physical, and biological analyzes; the financial, logistical and technical support of the Anglo American do Brasil mining company, Barro Alto-GO; and the administrative and technical support from the Eliseu Alves Foundation and its staff.

\section{Declarations}

'Not applicable'.

\section{Funding}

This research was partially supported by Anglo American and Embrapa

\section{Conflicts of interest}

The authors declare that the research was conducted in the absence of any commercial or financial relationships that could be construed as a potential conflict of interest.

\section{References}

1. Alencar A, Shimbo JZ, Lenti F, Marques CB, Zimbres B, Rosa M, Arruda V, Castro I, Ribeiro JPFM, Varela V, Alencar I, Piontekowski V, Ribeiro V, Bustamante MMC, Sano EE, Barroso M (2020) Mapping three decades of changes in the Brazilian Savanna native vegetation using Landsat Data processed in the Google Earth Engine Plataform. Remote Sens 12:1-23. https://doi.org/10.3390/rs12060924

2. Andrade LRM, Barros LMG, Echevarria GF, Amaral LIV, Cotta MG, Rossato DR, Haridasan M, Franco AC (2011) Al-hyperaccumulator Vochysiaceae from the Brazilian Cerrado store aluminum in their chloroplasts without apparent damage. Environ Exper Bot 70:37-42. https://doi.org/10.1016/j.envexpbot.2010.05.013

3. Andrade LRM, Aquino FG, Reis FB Jr, Pachêco BS, Echevarria G (2015) Potencial de uso de espécies vegetais nativas dos complexos ultramáficos. In: Barro Alto (GO) nos processos de recuperação de áreas alteradas pela extração de $\mathrm{Ni}$, de fitoextração e fitomineração de metais. Proceedins of the XXXV Congresso Brasileiro de Ciência do Solo: O solo e suas múltiplas funções. SBCS, Natal, RN, Brazil ) de 
4. Anglo A (2011) Anglo American inaugura oficialmente Unidade Barro Alto. https://brasil.angloamerican.com/pt-pt/imprensa/noticias/year2011/18-12-2011

5. Aquino FG, Viana RM, Miranda ZJG, Andrade LRM (2011) Floristic composition in the ultramafic soils in Central Brazil. Proceedings of the 7th International Conference on Serpentine Ecology, Coimbra, Portugal

6. Aziz H, Sabir M, Ahmad HR, Aziz T, Khalid MZ-u-R, Hakeem R, Ozturk M (2014) Alleviating effect of calcium on nickel toxicity in rice. CLEAN - Soil Air Water. https://doi.org/10.1002/clen.201400085

7. Baeta JDA Jr (1986) Ferro e metais da indústria do aço. In: Schobbenhaus Filho C, Coelho CES (eds) Principais Depósitos Minerais do Brasil. DNPM/Cia Vale do Rio Doce, Brasília

8. Baker DE, Amacher MC (1982) Nickel, Copper, Zinc, and Cadmium. In: RC Dinauer (ed) Methods of soil analysis - Part 2: Chemical and microbiological properties. Second edition edn. SSSA, Madison, USA

9. Baker AJM, Brooks RR (1989) Terrestrial higher plants which hyperaccumulate metallic elements - a review of their distribution, ecology and phytochemistry. Ecol Phytochem Biorecovery 1:81-126

10. Bradford MM (1976) A rapid and sensitive method for the quantification of microgram quantities of protein utilizing the principle of protein-dye binding. Anal Biochem 72:248-254. https://doi.org/10.1006/abio.1976.9999

11. Brady KU, Kruckeberg AR, Bradshaw HD Jr (2005) Evolutionary ecology of plant adaptation to serpentine soils. Ann Rev Ecol Syst 36:243-266.

https://doi.org/10.1146/annurev.ecolsys.35.021103.105730

12. Brown PH, Welch RM, Cary EE (1987) Nickel: A micronutrient essential for higher plants. Plant Physiol 85:801-803

13. Bussab WO, Miazak ES, Andrade DF (1990) Introdução à análise de agrupamentos. In Proceedings of the IX Simpósio Brasileiro de Probabilidade e Estatística. IME-USP, São Paulo

14. Cappa JJ, Pilon-Smits EAH (2014) Evolutionary aspects of hyperaccumulation. Planta 239:267-275. https://doi.org/10.1007/s00425-013-1983-0

15. Chang AC, Granato TC, Page AL (1992) A methodology for establishing phytotoxicity criteria for chromium, copper, nickel, and zinc in agricultural land application of municipal sewage sludges. $\mathrm{J}$ Environ Qual 21:521-534. https://doi.org/10.2134/jeq1992.00472425002100040001x

16. Clemens S (2001) Molecular mechanisms of plant metal tolerance and homeostasis. Planta 212:475-486

17. Correia JR, Reatto A, Spera ST (2004) Solos e suas relações com o uso e o manejo. In: Sousa DMG, E Lobato (eds) Cerrado: Correção do solo e adubação, 2nd. edn. Embrapa Informação Tecnológica, Brasília

18. Costa G, Spitz E (1997) Influence of cadmium on soluble carbohydrates, free amino acids, protein content of in vitro cultured Lupinus albus. Plant Sci 128:131-140. https://doi.org/10.1016/S01689452(97)00148-9 
19. Cruz CD (2013) GENES - a software package for analysis in experimental statistics and quantitative genetics. Acta Sci Agron 35:271-276. http://dx.doi.org/10.4025/actasciagron.v35i3.21251

20. Dubois M, Gilles KA, Hamilton JK, Rebers PA, Smith F (1956) Colorimetric method for determination of sugars and related substances. Anal Chem 28:350-356

21. Echevarria $G$ (2021) Genesis and behavior of ultramafic soils and consequences for nickel biogeochemistry. In: Van der Ent A, Baker AJM, Echevarria G, Simonnot M-O, Morel J-L (eds) Agromining: farming for metals: extracting unconventional resources using plants, 2nd edn. Springer International Publishing, Cham

22. Embrapa - Empresa Brasileira de Pesquisa Agropecuária (1999) Manual de análises químicas de solos, plantas e fertilizantes. Embrapa Solos, Rio de Janeiro

23. Faleiro FG, Faleiro ASG, Cordeiro MCR, Karia CT (2003) Metodologia para operacionalizar a extração de DNA de espécies nativas do cerrado. In: Embrapa Cerrados (ed), Planaltina, DF

24. Freitas FGd, Gomes IA, Ferreira RC, Antonello LL (1978) Levantamento de reconhecimento dos solos do Distrito Federal. In: Embrapa -SNLCS (ed) Boletim de Pesquisa no. 53. Embrapa-SNLCS, Rio de Janeiro

25. Gei V, Echevarria G, Isnard S, Fogliani B, Montargès-Pelletier E, Jaffré T, Spiers K, Garrevoet J, van der Ent A (2020) Soil chemistry, elemental profiles and elemental distribution in nickel hyperaccumulator species from New Caledonia. Plant Soil 57(1-2):293-320

26. Ghnaya AB, Hourmant A, Cerantola S, Kervarec N, Cabon JY, Branchard M, Charles G (2010) Influence of zinc on soluble carbohydrate and free amino acid levels in rapeseed plants regenerated in vitro in the presence of zinc. Plant Cell Tis Org Cult 102:191-197. https://doi.org/10.1007/s11240-0109721-9

27. Gomes JBV, Curi N, Motta PEF, Ker JC, Marques JJGSM, Schulze DG (2004) Análise de componentes principais de atributos físicos, químicos e mineralógicos de solos do bioma Cerrado. Rev Bras Ciênc Solo 28:137-153. https://doi.org/10.1590/S0100-06832004000100014

28. Goolsby EW, Mason CM (2016) Response: Commentary: Toward a more physiologically and evolutionarily relevant definition of metal hyperaccumulation in plants. Front Plant Sci 6:1-4. https://doi.org/10.3389/fpls.2015.01252

29. Hufford KM, Mazer SJ (2003) Plant ecotypes: genetic differentiation in the age of ecological restoration. Trends Ecol Evol 18:147-155. https://doi.org/10.1016/S0169-5347(03)00002-8

30. Jansen S, Broadley MR, Robbrecht E, Smets E (2002) Aluminum hyperaccumulation in angiosperms: a review of its phylogenetic significance. Bot Review 68:235-269

31. Jha AB, Dubey RS (2004) Carbohydrate metabolism in growing rice seedlings under arsenic toxicity. J Plant Physiol 161:867-872. https://doi.org/10.1016/j.jplph.2004.01.004

32. Kabata-Pendias A, Mukherjee AB (2007) Trace elements of Group 10 (Previously part of Group VIII). In: Kabata-Pendias A, Mukherjee AB Trace elements from soil to human. Springer, New York

33. Kim C-G, Power SA, Bell JNB (2003) Effects of cadmium and soil type on mineral nutrition and carbon partitioning in seedlings of Pinus sylvestris. Water Air Soil Pollut 145:253-266. 
https://doi.org/10.1023/A:1023610711837

34. Kraemer U (2010) Metal hyperaccumulation in plants. Annu Rev Plant Biol 61:517-534. https://doi.org/10.1146/annurev-arplant-042809-112156

35. Kruckeberg AR (2002) Geology and plant life: The effects of landforms and rock types of plants. University of Washington Press, Seattle

36. Lazcano-Ferrat I, Lovatt CJ (1999) Relationship between relative water content, nitrogen pools, and growth of Phaseolus vulgaris L. and $P$. acutifolius A. Gray during water deficit. Crop Sci, 39:467-475. https://doi.org/10.2135/cropsci1999.0011183X0039000200028x

37. Lopez S, Benizri E, Erskine PD, Cazes Y, Morel JL, Lee G, Permana E, Echevarria G, van der Ent A (2019) Biogeochemistry of the flora of Weda Bay, Halmahera Island (Indonesia) focusing on nickel hyperaccumulation. J Geochem Explor 202:113-127

38. Makela M, Michael P, Theriault G, Nkongolo KK (2016) High genetic variation among closely related red oak (Quercus rubra) populations in an ecosystem under metal stress: analysis of gene regulation. Gen Genom 38:967-976. https://doi.org/10.1007/s13258-016-0441-3

39. Martins ES, Becquer T, Brossard M (2010) Síntese de dados geoquímicos da região do Planalto Central - 1. Ocorrência de rochas ultramáficas na região de Cerrado contínuo e sua importância ecológica. In: LRM Andrade (ed) 20. Workshop do Projeto 02.07.01.007.00.00: "Relações entre metais do solo e a biodiversidade no Cerrado: ferramentas para a conservação ambiental e a recuperação de áreas degradadas". Embrapa Cerrados: DF

40. Martins ES, Reatto-Braga A, Carvalho-Junior OA, Guimarães RF (2004) Unidades de paisagem do Distrito Federal, escala 1:100.000. In: Embrapa Cerrados (ed) Série Documentos, 124. Embrapa Cerrados, Planaltina, DF

41. Mayr E (1947) Ecological factors in speciation. Evol 1:263-288. https://doi.org/10.2307/2405327

42. McKay JK, Christian CE, Harrison S, Rice KJ (2005) "How local is local?"- A Review of Practical and Conceptual Issues in the Genetics of Restoration. Rest Ecol 13:432-440. https://doi.org/10.1111/j.1526-100X.2005.00058.x

43. McNear DH, Peltier E, Everhart J, Chaney RL, Sutton S, Newville M, Rivers M, Sparks DL (2005) Application of quantitative fluorescence and absorption-edge computed microtomography to image metal compartmentalization in Alyssum murale. Environ Sci Technol 39:2210-2218

44. Mendonça RC, Felfili JM, Walter BMT, Silva-Júnior MC, Rezende AV, Filgueiras TS, Nogueira PE, Fagg CW (2008) Flora Vascular do Cerrado: checklist com 12.356 espécies. EMBRAPA Cerrados, Planaltina

45. Moreira MLO, Moreton LC, Araújo VA, Lacerda Filho JV, Costa HF (2008) Geologia do estado de Goiás e Distrito Federal: Texto explicativo do mapa geológico de Goiás e Distrito Federal. Programa Geologia do Brasil, Escala 1:500.000. CPRM, Goiânia, GO

46. Myers N, Mittermeier R, Mittermeier C, Fonseca GAB, Kent J (2000) Biodiversity hotspots for conservation priorities. Nature 403:853-858. https://doi.org/10.1038/35002501 
47. Nei M, Li WH (1979) Mathematical model for studying genetic variation in terms of restriction endonucleases. Proc Nat Ac Sci USA 76:5269-5273. https://doi.org/10.1073/pnas.76.10.5269

48. Paul ALD, Harris HH, Erskine PD, Przybyłowicz W, Mesjasz-Przybyłowicz J, Echevarria G, van der Ent A (2020) Synchrotron $\mu$ XRF imaging of live seedlings of Berkheya coddii and Odontarrhena muralis during germination and seedling growth. Plant Soil 453:487-501

49. Pennazio S (2012) Metals essentials for plants: the Nickel case. Theor Biol Forum 105:83-98

50. Pereira MdF, Valva FD, Coelho ASG, Aguiar AV, Zucchi MI (2004) Estrutura genética de populações de espécies arbóreas nativas do cerrado encontradas em terrenos serpentínicos. Pesq Agropec Trop 34:75-82. https://www.revistas.ufg.br/pat/article/view/2314

51. Pessoa-Filho M, Barreto CC, Reis FB Jr, Fragoso RR, Costa FS, Mendes IC, Andrade LRM (2015) Microbiological functioning, diversity, and structure of bacterial communities in ultramafic soils from a tropical savanna. Antonie Van Leeuwenhoek 107:935-949. http://doi.org/10.1007/s10482-0150386-6

52. Pollard AJ, Reeves RD, Baker AJM (2014) Facultative hyperaccumulation of heavy metals and metalloids. Plant Sci 217- 218:8-17. doi:http://doi.org/10.1016/j.plantsci.2013.11.011

53. Psaras GK, Manetas Y (2001) Nickel localization in seeds of the metal hyperaccumulator Thlaspi pindicum Hasusskn. Ann Bot 88:513-516. https://doi.org/10.1006/anbo.2001.1470

54. R Core Team (2014) R: A language and environment for statistical computing. R Foundation for Statistical Computing, Vienna, Austria. http://www.R-project.org/

55. Ratter JA, Ribeiro JF, Bridgewater S (1997) The Brazilian Cerrado vegetation and threats to its biodiversity. Ann Bot 80:223-230. https://doi.org/10.1006/anbo.1997.0469

56. Reeves RD, Baker AJM, Becquer T, Echevarria G, Miranda ZJG (2007) The flora and biogeochemistry of the ultramafic soils of Goiás state, Brazil. Plant Soil 293:107-119. https://doi.org/0.1007/s11104007-9192-x

57. Reeves RD, Baker AJM, Jaffré T, Erskine P, Echevarria G, van der Ent A (2018) A global database for plants that hyperaccumulate metal and metalloid trace elements. New Phytol 218(2):407-411

58. Reeves RD, van der Ent A, Echevarria G, Isnard S, Baker AJM (2021) Global distribution and ecology of hyperaccumulator plants. In: Van der Ent A, Baker AJM, Echevarria G, Simonnot M-O, Morel J-L (eds) Agromining: farming for metals: extracting unconventional resources using plants, 2ed. Springer International Publishing, Cham

59. Ribeiro JF, Machado B (2008) As principais fitofisionomias do bioma Cerrado. In: Sano SM, Almeida SP, Ribeiro JF (eds) Cerrado: Ecologia e Flora. Embrapa Cerrados/Embrapa Informação Tecnológica, Planaltina, pp 152-212

60. Robinson BH, Lombi E, Zhao FJ, McGrath SP (2003) Uptake and distribution of nickel and other metals in the hyperaccumulator Berkheya coddii. New Phytol 158:279-285

61. Rousseeuw P (1987) Silhouettes: A graphical aid to the interpretation and validation of cluster analysis. J Comput Appl Math 20:53-65. http://doi.org/10.1016/0377-0427(87)90125-7 
62. Sambroock J, Fritsch EF, Maniats T (1989) Molecular cloning: a laboratory manual. Cold Spring Harbor, New York

63. SAS Institute Inc (2008) SAS user's guide: statistic: version 9.1.3., Cary, NC, USA

64. Sellami R, Gharbi F, Rejeb S, Néji MR, Belgacem H, Echevarria G, Morel J-L (2012) Effects of nickel hyperaccumulation on physiological characteristics of Alyssum murale grown on metal contaminated waste amended soil. Int J Phytoremed 14:609-620.

http://doi.org/10.1080/15226514.2011.619225

65. Shannon JC (1968) A procedure for extraction and fractionation of carbohydrates from immature Zea mays kernels. Ind Agr Exp Sta Res Bull 842:1-8

66. Silva MAF, Assad DE, Evangelista AB (2008) Caracterização climática do Bioma Cerrado. In: Sano SM, Almeida SP, JF Ribeiro (eds) Cerrado: Ecologia e Fauna. Embrapa Informação Tecnológica, Brasília

67. Sneath PEA, Sokal RR (1973) Numerical taxonomy: the principles and practice of numerical classification. Freeman, San Francisco

68. StatSoft Inc (2007) Statistica for Windows (data analysis software system), version 7.1. StatSoft, Tulsa, OK, USA

69. van der Ent A, Baker AJM, Reeves RD, Pollard AJ, Schat H (2013) Hyperaccumulators of metal and metalloid trace elements: facts and fiction. Plant Soil 362(1):319-334

70. van der Ent A, Baker AJM, Reeves RD, Chaney RL, Anderson CW, Meech JA, Mulligan DR, Erskine PD, Simonnot M-O, Vaughan J, Morel J-L, Echevarria G, Fogliani B, Rongliang Q, Mulligan DR (2015a) Agromining: farming for metals in the future? Environ Sci Technol 49:4773-4780. http://doi.org/10.1021/es506031u

71. van der Ent A, Baker AJM, Reeves RD, Pollard AJ, Schat H (2015b) Commentary: Toward a more physiologically and evolutionarily relevant definition of metal hyperaccumulation in plants. Front Plant Sci 6:1-3. http://doi.org/10.3389/fpls.2015.00554

72. van der Ent A, Spyers K, Brueckner D, Echevarria G, Aarts MGM, Montargès-Pelletier E (2019) Spatially-resolved localization and chemical speciation of nickel and zinc in Noccaea tymphaea and Bornmuellera emarginata. Metallomics 11:2052-2065

73. Vidal-Torrado P, Macias F, Calvo R, Carvalho SGd, Silva AC (2006) Gênese de solos derivados de rochas ultramáficas serpentinizadas no sudoeste de Minas Gerais. R Bras Ci Solo 30:523-541. https://doi.org/10.1590/S0100-06832006000300013

\section{Tables}

Due to technical limitations, table 1 to 6 is only available as a download in the Supplemental Files section.

\section{Figures}



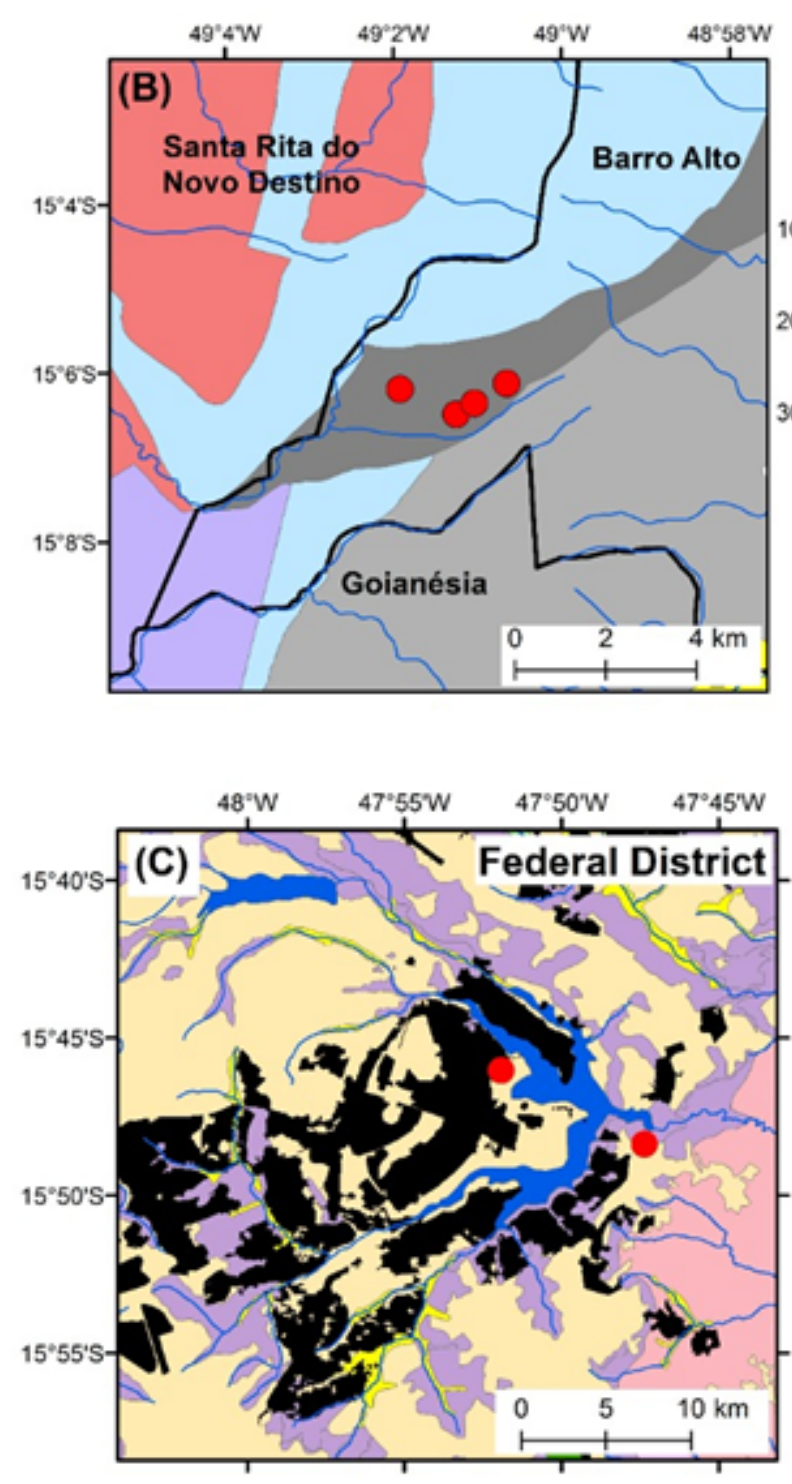

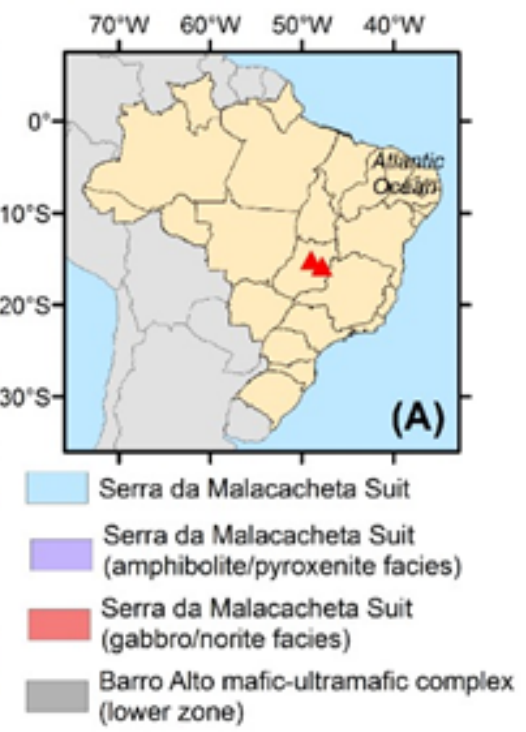

Barro Alto mafic-ultramfic complex (Ultramafic zone)

Alluvial deposit

Vegetation and soil sampling site

Drainage

Municipality boundary

Canastra Group, Paracatu Formation

Paranoá Group, Unit 3

Paranoá Group, Unit 3

Paranoá Group, Unit 4

Canastra Group, Serra do Landim

Formation

Ferruginous, detritus-lateritic deposit

Bambui Group, Serra da Saudade

Formation

Alluvial deposit

Water body

Urban area

\section{Figure 1}

Location of the study areas in the Goiás State and in Federal District of Brazil (A). Location of vegetation and soil samplings in the municipality of Barro Alto, Goiás State (B) and in Federal District (C). The background map corresponds to the 1:500,000 scale soil map proposed by the Brazilian Geological Survey (CPRM) (adapted from Moreira et al. 2008). Note: The designations employed and the presentation of the material on this map do not imply the expression of any opinion whatsoever on the part of Research Square concerning the legal status of any country, territory, city or area or of its authorities, or concerning the delimitation of its frontiers or boundaries. This map has been provided by the authors. 


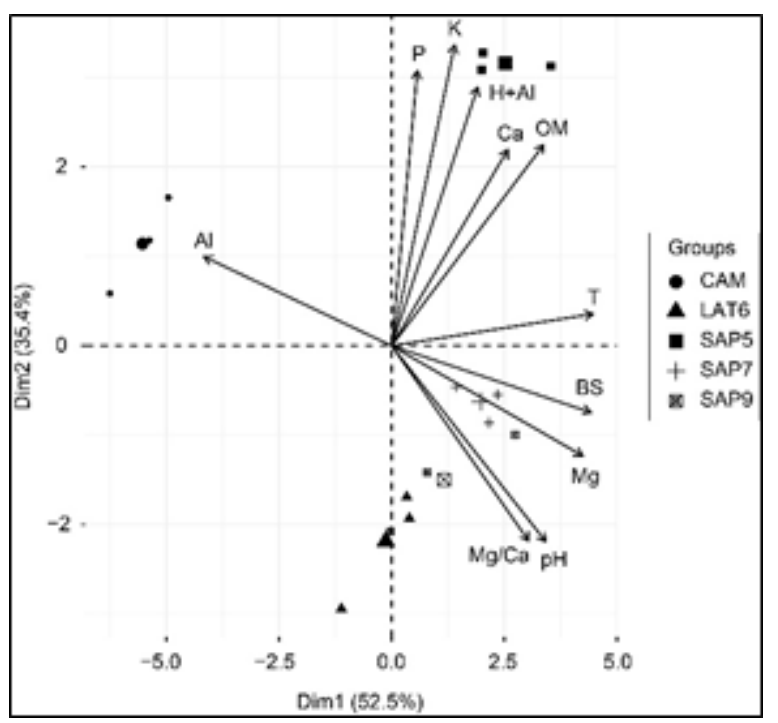

Figure 2

Principal component analysis (PCA) representing the correlation of the sites according to the chemical attributes of the soils. The arrows represent the ability of each attribute to separate the sites where the botanical access collections were obtained. The values in parentheses on each axis refer to the percentage of variance.
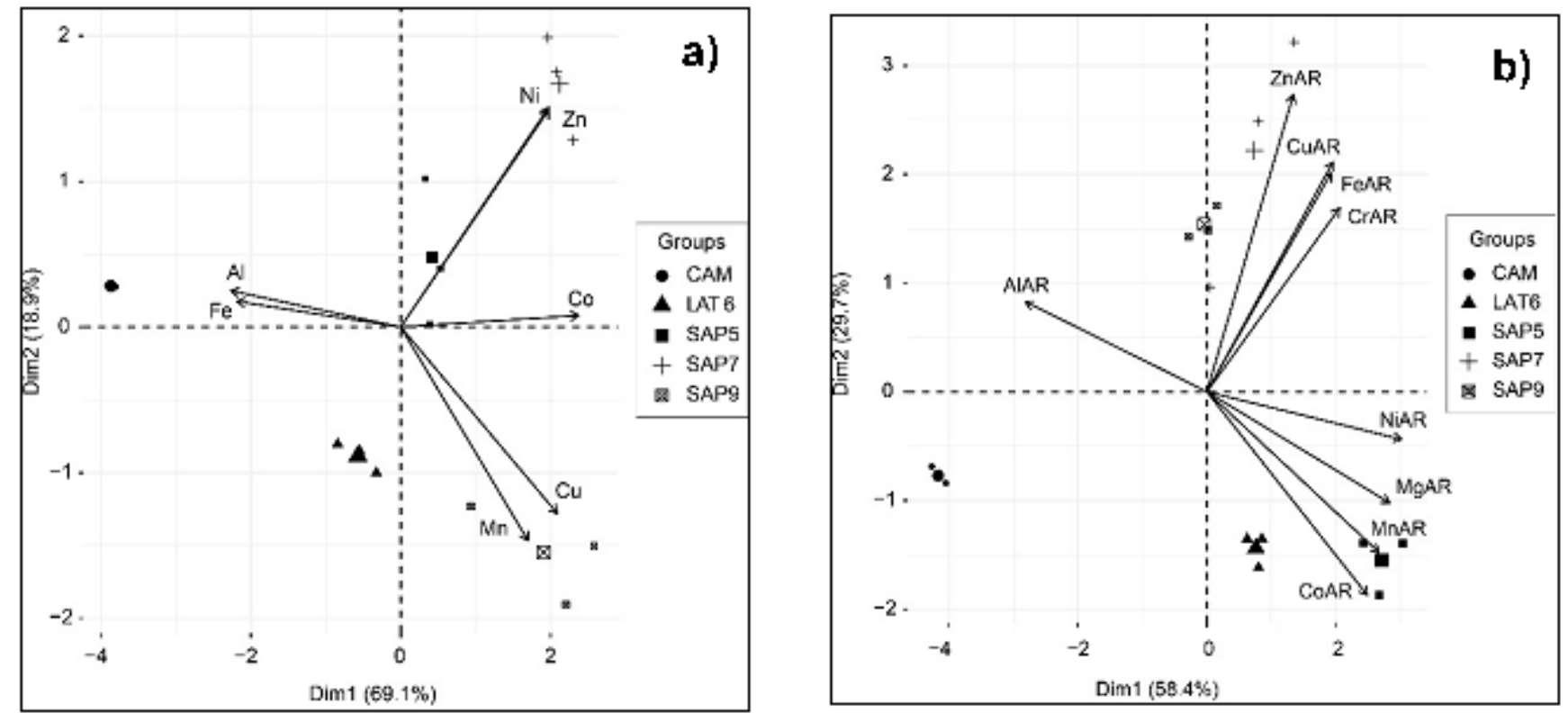

\section{Figure 3}

Principal component analysis (PCA) representing the correlation of the sites according to the chemical attributes referred to a) the bioavailability (DTPA) of metals and b) Aqua Regia extractable content of metals (AR). The arrows represent the ability of each attribute to separate the sites where the botanical access collections were made. The values in parentheses on each axis refer to the percentage of variance. 


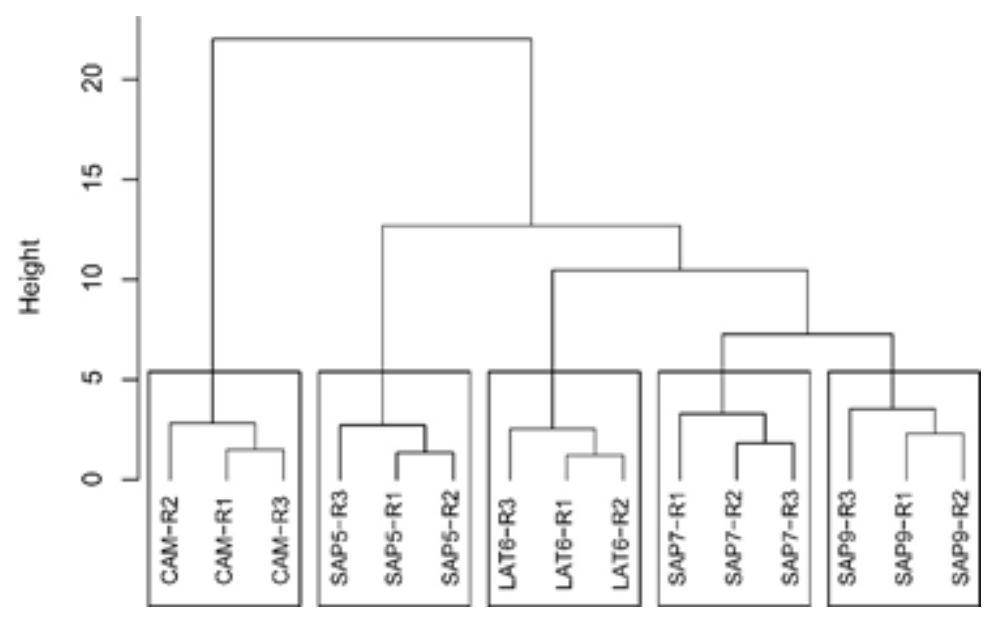

\section{Figure 4}

Cluster analysis of the sites according to the dissimilarities between the attributes of fertility, metals bioavailability and semi-total metals content in the soils where the botanical access collections were made.

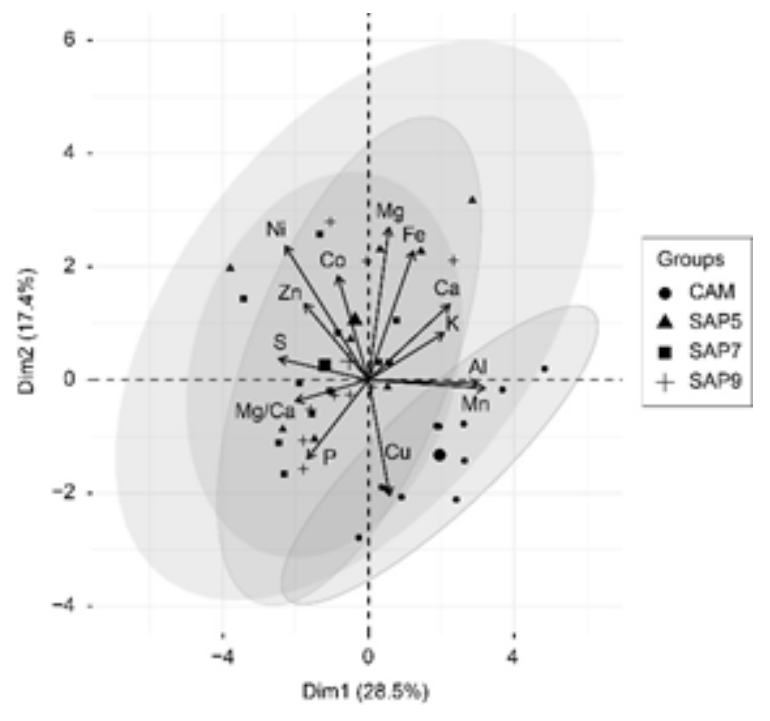

Figure 5

Principal component analysis (PCA) representing the correlation of the sites according to the chemical elements in plants tissue of the accessions collected in ultramafic (SAP) and non-ultramafic (CAM) sites. The arrows represent the ability of each attribute to separate the sites where the botanical access collections were made. The values in parentheses on each axis refer to the percentage of variance. 

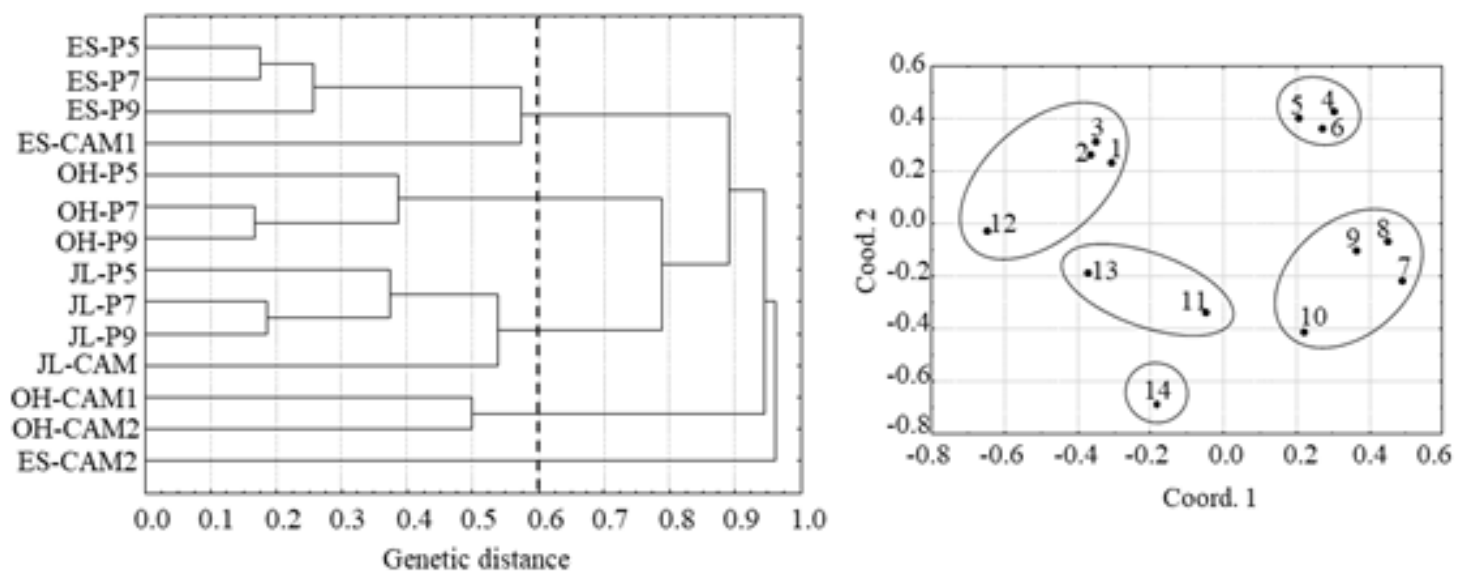

\section{Figure 6}

Cluster analysis and graphical dispersion of 14 accessions based on the genetic dissimilarity matrix calculated from 108 ISSR markers. The UPGMA method was used as the grouping criterion. The principal coordinate method was used in the graphical dispersion analysis. The value of the coffonetic correlation coefficient ( $r$ ) was 0.88 . The access numbers in the scatter plot correspond to the access numbers shown in Table 1.
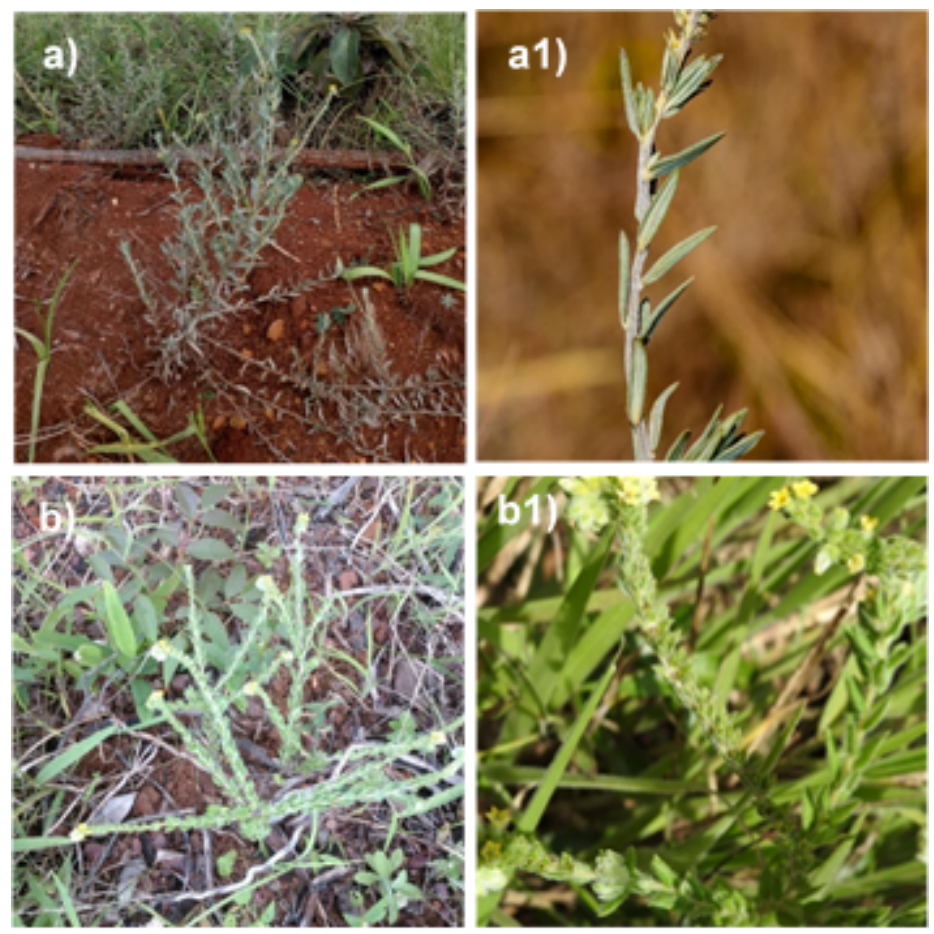

Figure 7

General aspect of Euploca salicoides plants a) E. salicoides growing in ultramafic site (high $\mathrm{Ni}$ bioavailability), and a1) detail of a branch with long internodes; b) E. salicoides growing in typical Cerrado site, in soil poor in $\mathrm{Ni}$, and b1) detail of a highly hairy branch with short internodes. 

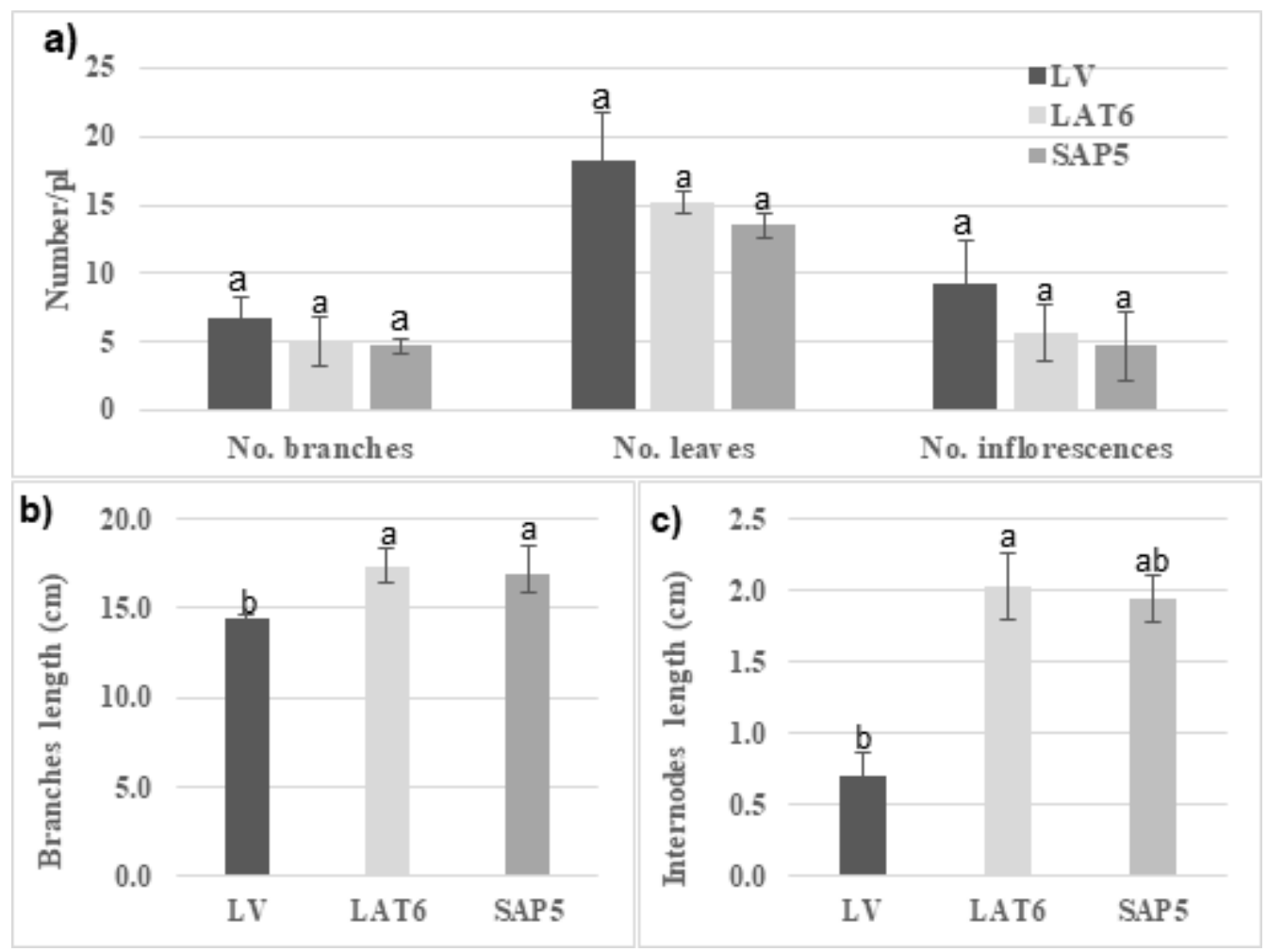

Figure 8

Morphological parameters of E. salicoides plants growing in three sites with different edaphic characteristics (LV, LAT6 and SAP5). a) Number of branches, leaves and inflorescences per plant; $b$ ) average length of branches, and $c$ ) average length of internodes. $n=$ three plants per site. Bars represent standard deviation of the mean. Means followed by same letters are not statistically different $(p>0.05)$

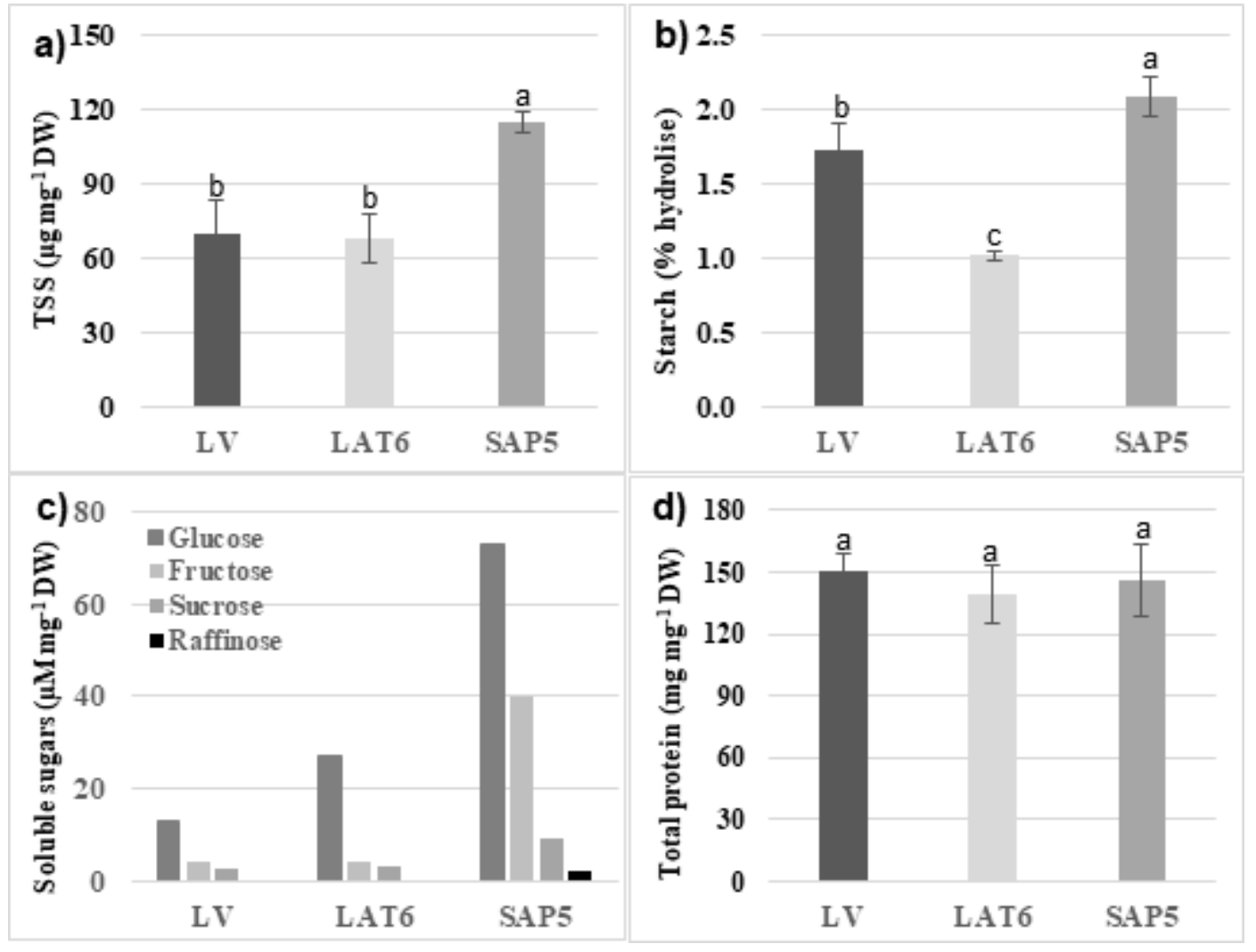




\section{Figure 9}

Carbohydrate contents in E. salicoides plants growing in three sites (LV, LAT6, and SAP5), with different edaphic characteristics. a) total soluble sugars (TSS); b) starch; c) content of soluble sugars, as monosaccharides (glucose and fructose) and oligosaccharides (sucrose and raffinose); and d) total soluble proteins. Bars represent standard deviation of the mean. Means followed by same letters are not statistically different $(p>0.05)$.

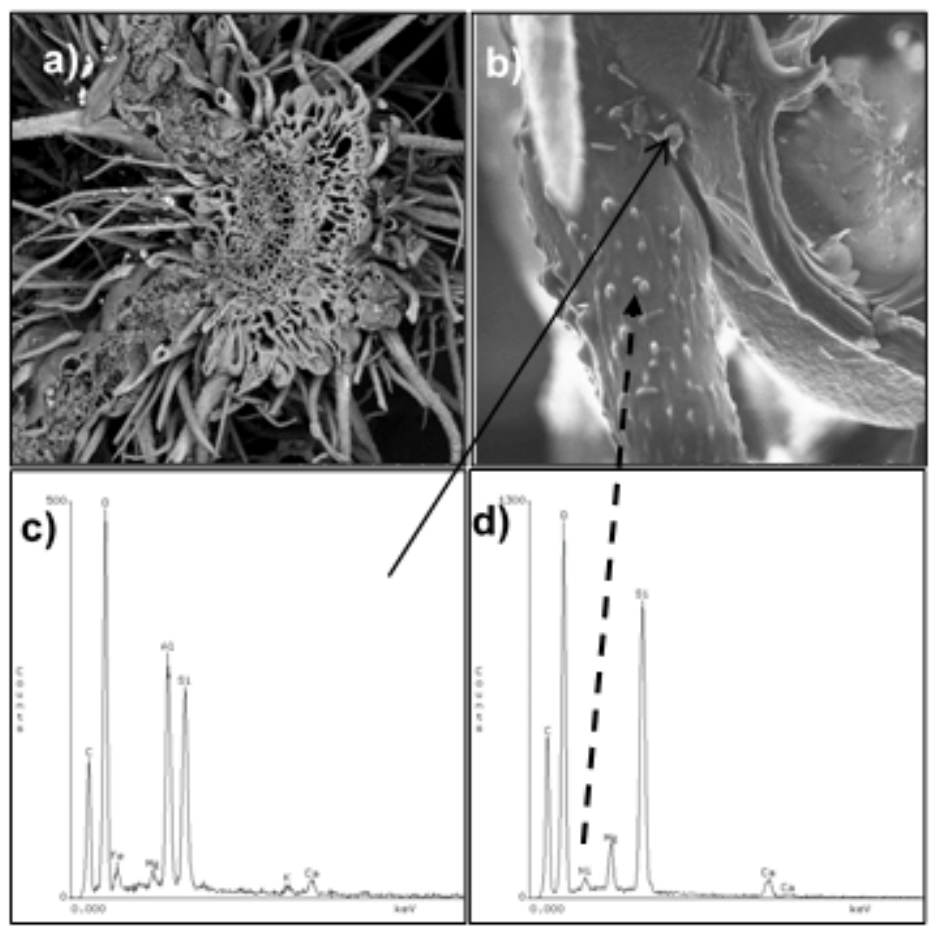

Figure 10

SEM images of a) central rib; b) trichomes of E. salicoides in leaf blade, cultivated in soil with high $\mathrm{Ni}$ bioavailability (SAP5) and X-ray emission spectra intensities of elements: c) "dust" trapped between trichomes; and d) trichomes - Ni peak is shown only in protrusions of trichomes $(k v=10)$

\section{Supplementary Files}

This is a list of supplementary files associated with this preprint. Click to download.

- Tables.docx 